\title{
Electrospun Medicated Nanofibers for Wound Healing: Review
}

\author{
Xinkuan Liu ${ }^{1, *}$, Haixia $\mathrm{Xu}^{1}{ }^{1}$, Mingxin Zhang ${ }^{1}\left(\mathbb{D}\right.$ and Deng-Guang $\mathrm{Yu}^{1,2}$ \\ 1 School of Materials Science and Engineering, University of Shanghai for Science and Technology, \\ Shanghai 200093, China; 193742716@st.usst.edu.cn (H.X.); 203613006@st.usst.edu.cn (M.Z.); \\ ydg017@usst.edu.cn (D.-G.Y.) \\ 2 Shanghai Engineering Technology Research Center for High-Performance Medical Device Materials, \\ Shanghai 200093, China \\ * Correspondence: xinkuanliu@usst.edu.cn
}

check for updates

Citation: Liu, X.; Xu, H.; Zhang, M.; Yu, D.-G. Electrospun Medicated Nanofibers for Wound Healing: Review. Membranes 2021, 11, 770. https://doi.org/10.3390/ membranes 11100770

Academic Editors: Yu-Kaung Chang and Ooi Chien Wei

Received: 14 September 2021

Accepted: 6 October 2021

Published: 9 October 2021

Publisher's Note: MDPI stays neutral with regard to jurisdictional claims in published maps and institutional affiliations.

Copyright: (c) 2021 by the authors. Licensee MDPI, Basel, Switzerland. This article is an open access article distributed under the terms and conditions of the Creative Commons Attribution (CC BY) license (https:/ / creativecommons.org/licenses/by/ $4.0 /)$.

\begin{abstract}
With the increasing demand for wound care and treatment worldwide, traditional dressings have been unable to meet the needs of the existing market due to their limited antibacterial properties and other defects. Electrospinning technology has attracted more and more researchers' attention as a simple and versatile manufacturing method. The electrospun nanofiber membrane has a unique structure and biological function similar to the extracellular matrix (ECM), and is considered an advanced wound dressing. They have significant potential in encapsulating and delivering active substances that promote wound healing. This article first discusses the common types of wound dressing, and then summarizes the development of electrospun fiber preparation technology. Finally, the polymers and common biologically active substances used in electrospinning wound dressings are summarized, and portable electrospinning equipment is also discussed. Additionally, future research needs are put forward.
\end{abstract}

Keywords: wound dressing; electrospinning; nanostructure; nanocomposite

\section{Introduction}

Skin is the largest important organ of the human body and the first barrier against external pathogens [1]. However, external mechanical forces, surgical operations, burns, chemical injuries, and ulcers from certain chronic diseases can cause varying degrees of damage to the skin [2]. Wound healing is a complicated and dynamic process of tissue regeneration, mainly composed of four stages: hemostasis, inflammation, proliferation, and remodeling [3]. Although the skin can undergo a certain degree of spontaneous repair, bacterial infection has always been the main reason hindering wound healing. For an infected wound, it will not only disrupt the normal healing process, but also cause the wound tissue to be deformed, causing great pain to the patient [4].

Wound dressings play an essential role in wound healing management. They protect the wound from external risk factors, and speed up the healing process [5]. On the basis of the mechanism of wound healing, an ideal wound dressing ought to have the accompanying attributes: (1) absorb excess exudate; (2) protect the wound from microbial infection; (3) maintain a moist healing environment at the wound site; (4) facilitate gas exchange; (5) non-toxic, biocompatible, and degradable; (6) does not adhere to the wound, easy to replace and remove; (7) promote angiogenesis and tissue regeneration [6-8]. Different wound needs should be integrated when choosing wound dressings. So far, the common dressings on the market mainly include film [9], foam [10], sponge [11], hydrogel [12,13], and nanofiber membrane $[14,15]$. Among these materials, the unique structure of the small pore size and high porosity of the nanofiber membrane can protect the wound from pathogen infection and ensure the free transportation of gas and liquid molecules. At the same time, a large amount of research has been carried out, combining the adjustable characteristics of physical and mechanical properties to make it stand out among biomaterials [16,17]. 
So far, methods such as drawing [18], self-assembly [19], phase separation [20] and template synthesis [21] have been used to prepare nanofibers. However, they have disadvantages such as high cost, time-consuming and low efficiency. Therefore, simple and practical electrospinning technology is widely used to manufacture fibers with diameters in the nanometer or micrometer range [22]. Electrospun nanofiber membranes represent a new class of materials. Because of their high surface-to-volume ratio, high microporosity and versatility, they can be used in various biomedical applications [23], such as tissue engineering scaffolds [24,25], drug delivery [26-28] and wound dressings [29,30]. Nanofiber wound dressings prepared by electrospinning technology have many advantages. First, the structure and biological function are similar to the natural extracellular matrix $(\mathrm{ECM})$, which provides an ideal microenvironment for cell adhesion, proliferation, migration and differentiation $[31,32]$. Secondly, the polymer matrix used for electrospinning can simultaneously combine the biocompatibility of natural polymers and the reliable mechanical strength of synthetic polymers [33]. Furthermore, the nanofiber membrane's wide surface area and porous structure can be effectively loaded with various biologically active ingredients, including antibacterial drugs, inorganic nanoparticles, vitamins, growth factors and Chinese herbal extracts. The rate and time of drug release are controlled by adjusting the fiber structure and morphological size, thereby promoting effective healing of the wound site [34]. Therefore, electrospun nanofibers show great potential in the preparation of advanced bioactive wound dressings.

In recent years, on the "Web of Science" platform, the subject of "Wound dressing" and "Electrospun wound dressing" has been searched among the literature. The statistical results are shown in Figure 1. The number of relevant documents corresponding to the two topics has shown a substantial increase year by year. Among them, the literature with the theme of "Wound dressing" has maintained thousands of articles every year from 2010 to the end of 2020, indicating that wound dressing has become a hot research topic in recent years. At the same time, the number of documents retrieved with the theme of "Electrospun wound dressing" has maintained more than a hundred articles in the past five years, indicating that electrospun nanofibers are developing into a new type of wound dressing with broad application prospects. This article reviews the research progress and application prospects of electrospun medical nanofibers used in wound dressings. The new strategy of electrospinning technology for preparing nanofiber wound dressings is described in detail.

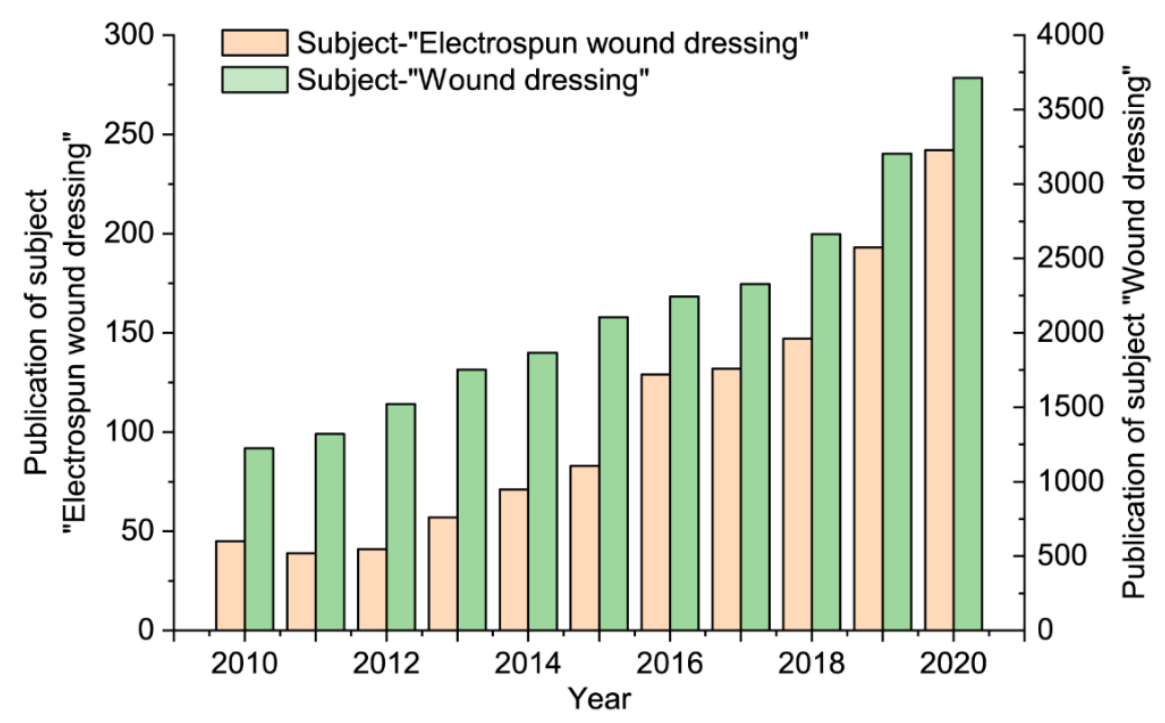

Figure 1. Statistics of literature retrieval on the "Web of Science" platform with the subject of "Wound dressing" and "Electrospun wound dressing", respectively. 


\section{Wound and Wound Dressing}

\subsection{Wounds Classification}

Wounds are defined as skin deformities or tissue discontinuities brought about by physical or thermal injury, or underlying ailments [35]. Given the nature and duration of the healing process, wounds are usually divided into acute and chronic types [36]. Acute wounds mainly include mechanical injuries, chemical injuries, surface burns and surgical wounds, etc. The healing process follows the normal wound healing cycle [37-39]. However, chronic wounds refer to those cannot go through an orderly healing process and have been open for more than one month. The causes of chronic wounds vary, and are mainly related to certain specific diseases (such as diabetes). They are notorious for the terrible incidence of ulcers, and they are susceptible to infection by inflammatory bacteria that affect wound repair [40,41]. Globally, chronic wounds impose a heavy burden on patients and healthcare systems [42].

\subsection{Types of Wound Dressing}

In 1962, Dr. Jorge Winter of the University of London put forward the "moist healing environment theory" first, and related studies confirmed that a moist environment will speed up the wound healing process [43]. In recent years, the theory of moist healing has received extensive consideration. The U.S. Food and Drug Administration (FDA) pointed out in an industry guide issued in August 2000 that one of the standard methods of wound treatment is to maintain a moist environment on the wound surface [44]. With the in-depth study of wound healing, the types of wound treatment and dressings are constantly improving and developing [45]. Wound dressings are classified into traditional wound dressing, modern wound dressing and bioactive wound dressing according to their functional properties and wound origin. Table 1 classifies and summarizes wound dressings based on their functions.

Table 1. Types of wound dressing.

\begin{tabular}{|c|c|c|c|c|}
\hline Nature & Category & Advantages & Disadvantages & Ref. \\
\hline $\begin{array}{l}\text { Traditional } \\
\text { wound } \\
\text { dressing }\end{array}$ & Gauze, lint, bandage & Easy to use and economical & $\begin{array}{l}\text { 1. Dry, unable to maintain a moist healing } \\
\text { environment } \\
\text { 2. Adhering to the wound site is difficult to } \\
\text { remove }\end{array}$ & {$[46]$} \\
\hline \multirow{5}{*}{$\begin{array}{l}\text { Modern } \\
\text { wound } \\
\text { dressing }\end{array}$} & Film & $\begin{array}{l}\text { 1. Transparent, can observe } \\
\text { wound changes } \\
\text { 2. Form a bacterial barrier } \\
\text { 3. Gas and water vapor permeability }\end{array}$ & $\begin{array}{l}\text { 1. Absorptive capacity is not strong } \\
\text { 2. Obstruct the regeneration of } \\
\text { epithelial tissue }\end{array}$ & [47] \\
\hline & Foam & $\begin{array}{l}\text { 1. High water absorption performance to } \\
\text { maintain the moist environment of } \\
\text { the wound } \\
\text { 2. Change the dressing without damage }\end{array}$ & $\begin{array}{l}\text { 1. Weak adhesion } \\
\text { 2. Completely opaque }\end{array}$ & [48] \\
\hline & Hydrocolloid & $\begin{array}{l}\text { 1. Stimulate tissue autolysis } \\
\text { and debridement } \\
\text { 2. The closed structure blocks the invasion } \\
\text { of external bacteria }\end{array}$ & $\begin{array}{l}\text { 1. Poor degradability } \\
\text { 2. Produce a special smell }\end{array}$ & [49] \\
\hline & Hydrogel & $\begin{array}{l}\text { 1. Ability to replenish water and maintain } \\
\text { a humid environment } \\
\text { 2. Comfortable and easy to replace }\end{array}$ & $\begin{array}{l}\text { 1. No adhesion, low mechanical strength } \\
\text { 2. High water content, limited absorption } \\
\text { capacity, not suitable for wounds with high } \\
\text { exudate }\end{array}$ & {$[50]$} \\
\hline & Alginate & $\begin{array}{l}\text { 1. Non-toxic, fast hemostasis } \\
\text { 2. Good air permeability } \\
\text { 3. Biodegradation }\end{array}$ & Not suitable for dry wounds & {$[51]$} \\
\hline $\begin{array}{l}\text { Bioactive } \\
\text { wound } \\
\text { dressing }\end{array}$ & $\begin{array}{l}\text { Drug-loaded dressing, } \\
\text { antibacterial dressing }\end{array}$ & $\begin{array}{l}\text { 1. Good biocompatibility } \\
\text { 2. Anti-inflammatory and antibacterial } \\
\text { 3. Promote the growth of cells and tissues }\end{array}$ & Induce immune response & {$[52]$} \\
\hline
\end{tabular}




\subsubsection{Traditional Wound Dressing}

Traditional wound dressings mainly use gauze, lint and bandages as dressings, which are the most widely used wound dressings. However, it does not absorb and drain the exudate from the wound site smoothly during use, and cannot maintain a moist healing environment. The porous structure on the surface cannot prevent the invasion of external bacteria and will promote the migration of bacteria to the wound site in a humid environment. It is easy to adhere to the wound exudate during use, so it will cause secondary damage to the skin when replaced [53].

\subsubsection{Modern Wound Dressing}

Compared with traditional dressings, modern wound dressings have better biocompatibility, moisture retention and degradability [54]. Standard high-end modern dressings include film, foam, hydrocolloid, hydrogel and alginate dressings, etc., which provide a more effective healing effect than traditional dressings [47]. The film is a light, thin and elastic transparent polyurethane or synthetic polymer adhesive. The transparent surface can permeate not only water vapor and oxygen, but is also convenient to observe the healing of the wound [55]. Foam dressings are usually composed of a hydrophilic polymer layer and a hydrophobic polyurethane absorbent layer. The polymer layer is permeable to gas and semi-permeable to fluids. The inner layer structure is used to absorb exudate, and the outer layer is used to prevent the wound from drying out and prevent it from being invaded by bacteria [56]. Hydrocolloid dressing is a new type of wound dressing widely used in clinical practice, which is made of water or glycerin-based polymer materials. After absorbing the liquid, it will swell to form a gel, and the dressing will become soft [57]. Hydrogel dressings are cross-linked polymer networks made of carbohydrate-based materials, which can be made into various thicknesses and are widely used in drug delivery and tissue repair [58]. Alginate dressings are a dressing prepared with different types of seaweed or algae polysaccharides. It has a high fluid absorption capacity and promotes autolytic debridement to soften and eliminate necrotic tissue. It is often used for chronic wounds with high exudate fluid, deep burns and surgical wounds that require hemostasis [59].

\subsubsection{Bioactive Wound Dressing}

As a new type of wound dressing, bioactive wound dressings are used to expedite the healing of various types of wounds [60]. This dressing is made of various polymers, such as gelatin, silk fibroin, chitosan, alginate, etc., and is applied in the form of foam, sponge, film, hydrogel and nanofiber membrane (Figure 2) [6,61]. Biologically active substances such as antibacterial drugs, growth factors, nanoparticles and natural products are added to obtain antibacterial activity, promote fibroblast activity and endothelial cell migration [62]. In short, the development of functionalized bioactive dressings is a crucial step in developing wound dressings.

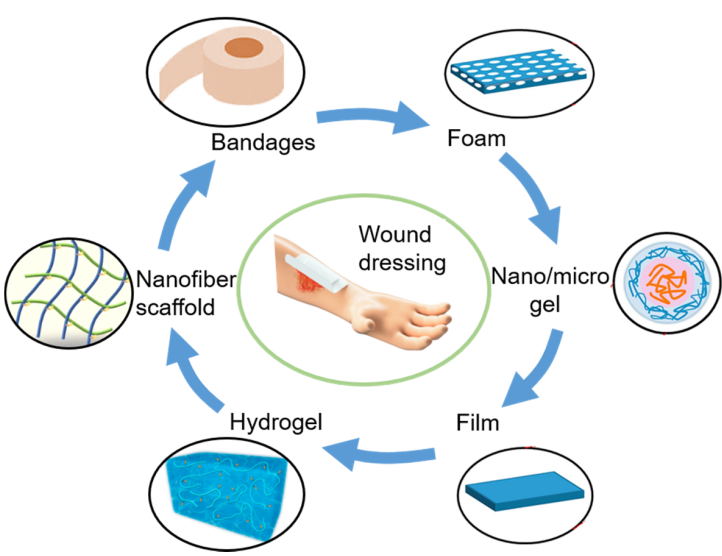

Figure 2. Structure of different wound dressing. 


\section{Electrospinning Technology}

\subsection{Introduction to Electrospinning Technology}

Electrospinning technology, as a superfine fiber preparation technology, has experienced hundreds of years of development [63]. The electrostatic spinning device is mainly composed of four parts: a high-voltage generator, a fluid driver, a spinneret and a collection device [64]. In the electrospinning process, the initial electrospinning fluid gradually changes its morphology after the voltage is applied, until it reaches the critical voltage shape into a Taylor cone. When the liquid jet stretches over a certain distance, it enters the bending and whiplash stage. With the solvent volatilization, the jet is stretched to micrometers or even tens of nanometers, finally solidified and deposited on the collector to form nanofiber $[65,66]$. On the basis of this principle, the electrospinning process can be adjusted by system parameters (polymer type, molecular weight, viscosity, conductivity of the solution, surface tension), process parameters (voltage, flow rate, receiving distance) and environmental parameters (humidity, temperature) to change the morphology and size of nanofibers $[67,68]$. As a simple, top-down one-step preparation method, electrospinning technology produces nanofibers with small pore size, high porosity and a structure similar to ECM. Therefore, it has received extensive attention from researchers and used to prepare functionalized nanofibers for applications in biomedicine and other fields [69-71]. At the same time, the electrospinning technology is continuously upgraded and optimized. As shown in Figure 3, it has gradually developed into single fluid electrospinning (blend electrospinning and emulsion electrospinning), double-fluid electrospinning (coaxial electrospinning and side-by-side electrospinning) and multifluid electrospinning (triaxial electrospinning and other multifluid electrospinning).

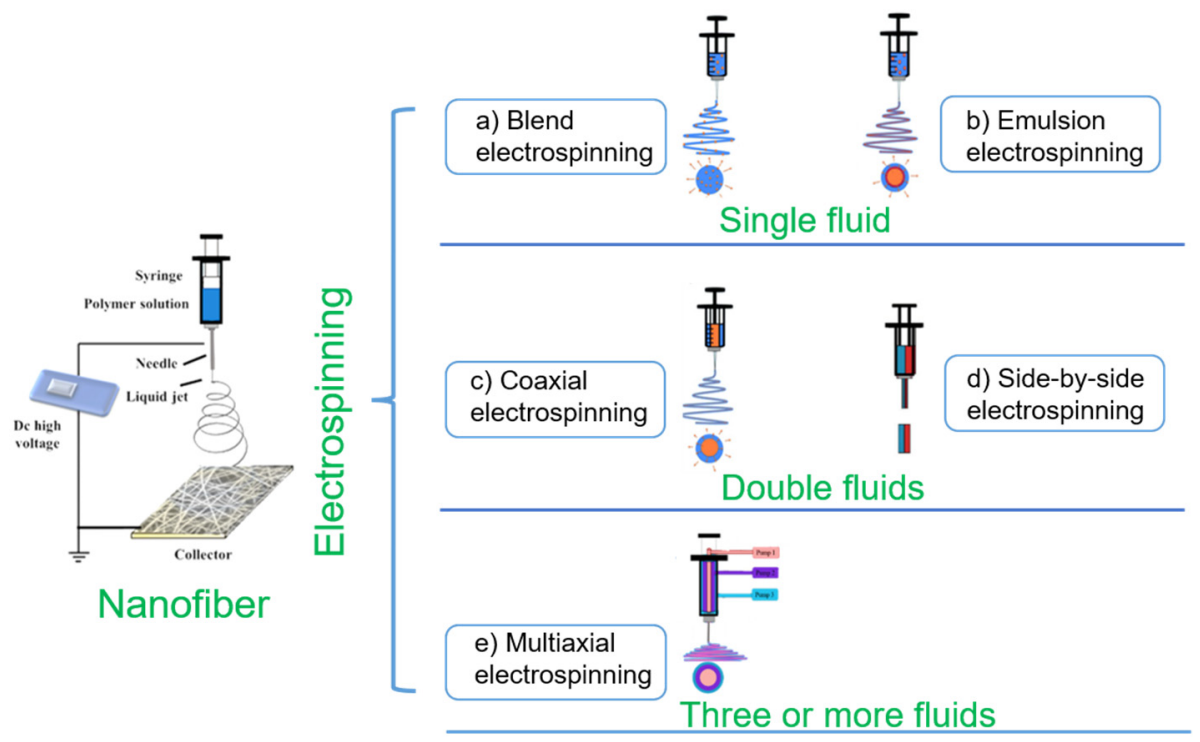

Figure 3. Process classification of electrospinning technology (adapted from [72], with permission from MDPI, 2021).

\subsection{Single Fluid Electrospinning}

\subsubsection{Blend Electrospinning}

Blend electrospinning is the most common method for preparing blended nanofibers. A suitable solvent is usually selected in the preparation process, which can dissolve the polymer used and the drug added. If the polymer-dissolving solvent cannot dissolve the drug, it is possible to add a small amount of the drug-soluble solvent to dissolve them together [73]. If the dissolvability of the drug in the polymer solution is low, a large amount of the drug will be present on the surface of the prepared fiber. As a result, an explosive release of drugs occurs, which is also the main weakness of hybrid electrospinning [74]. 


\subsubsection{Emulsion Electrospinning}

Emulsion electrospinning is a simple and standard method for preparing nanofibers with a core-shell structure, which could effectively load drugs [75]. Different from the blend electrospinning mentioned above, the hydrophilic drugs in emulsion electrospinning are usually dissolved in the water phase and then diffused into the oil phase containing surfactants/emulsifiers. The water/oil emulsion obtained after electrospinning forms nanofibers with a core-shell structure in which the drug is included in the core [76]. Therefore, it shows superior performance in the properties of encapsulating biologically active substances, e.g., proteins and drugs [77]. Zhan et al. [78] reported that using polyvinyl alcohol (PVA) and polyacrylic acid (PAA) as polymers, electrospun nanofibers loaded with tangeretin (Tan) were prepared by the emulsion electrospinning method. In vitro drug release results show that PVA/PAA/Tan nanofibers have longer-lasting release characteristics and a lower initial burst release rate than pure Tan emulsion. This work provides a promising technology for the preparation of insoluble drug release and drug delivery systems.

\subsection{Double-Fluid Electrospinning}

\subsubsection{Coaxial Electrospinning}

Among the various multifluid electrospinning techniques, coaxial electrospinning is the most basic one, which is widely used to manufacture core-sheath nanofibers [79]. In the core-sheath nanofibers, if a drug-loaded hydrophilic polymer is selected as the core solution, voids will be formed in the sheath fiber after it is dissolved. At this time, the hydrophobic shell serves as an outer protective layer to prevent initial burst release. By loading different forms of sheath polymer, two different release forms can be achieved to control the release of drugs [80]. Therefore, coaxial electrospinning is considered one of the most significant breakthroughs in the field of drug-sustained release [81,82]. Yan et al. [83] successfully prepared PH-sensitive PVA/polycaprolactone (PCL) core-shell nanofibers using coaxial electrospinning technology, achieving sustained $\mathrm{PH}$-responsive release of the anticancer drug doxorubicin (DOX).

With the in-depth study of electrospinning technology, researchers have discovered that the traditional coaxial electrospinning technology has the problem of poor ability to manage the morphology of the fiber. At the same time, more and more research is devoted to treating unspinnable fluids in multifluid work. If they are used as a sheath liquid and work with a spinnable core fluid, they can be converted into nanofibers [84]. In 2010, Yu et al. [85] reported the use of pure solvents (unspinnable fluid) as the sheath working fluid to conduct electrospinning experiments, which effectively prevented the clogging of the spinneret during the spinning process; high-quality nanofibers with smooth surfaces were prepared. Later, the coaxial/triaxial process using unspinnable fluid as the sheath fluid was called modified coaxial/triaxial electrospinning.

\subsubsection{Side by Side Electrospinning}

In 2003, Gupta and Wilkes first reported the use of side-by-side electrospinning to prepare Janus nanofibers [86]. The Janus structure is one of the most basic structures. Different from the traditional core-sheath structure, its two chambers are separated from each other and both are in contact with the surrounding environment. In side-by-side electrospinning, nanofibers with different properties can be prepared by designing the structure of the spinneret and adjusting the electrospinning parameters [87-89]. Zheng et al. conducted a study on the effect of the bilateral drug loading of electrospun Janus nanofibers on the two-phase controlled release of the anticancer drug tamoxifen (TAM), and described the related mechanisms. It can be found from the drug release curve that different polymer components, different two-compartment structures and shapes have a significant impact on the in vitro release characteristics of TAM. They have also been proven to be important elements in the design of functional nanomaterials [90]. 


\subsection{Multifluid Electrospinning}

\subsubsection{Triaxial Electrospinning}

With the rapid development of nanotechnology, researchers are not satisfied with the development and application of secondary structures. They have begun to devote themselves to the research of triaxial and even multiaxial electrospinning to meet the needs of different fields [91]. Naveen et al. [92] used poly (lactic-co-glycolic-acid) (PLGA) as the sheath fluid, gelatin as the intermediate layer, PCL as the core layer, Rhodamine B $(\mathrm{RhB})$ and Bovine Serum Albumin (BSA) was loaded into the outer and intermediate layer solutions, respectively, a triaxial electrospinning was performed. The prepared nanofibers show excellent mechanical properties and dual drug release capabilities.

Later, Ding et al. [93] used PH-sensitive polymer Eudragit S100 (ES100) as a matrix, loaded with a model drug aspirin, prepared core-shell nanofibers using a modified triaxial electrospinning technology. Compared with traditional single fluid electrospun nanofibers, in vitro drug release exhibits a longer-term sustained release of aspirin, avoiding cytotoxicity caused by short-term excessive drug release. Subsequently, Zhao et al. followed the technology of the research group and used the prepared nanofiber membranes loaded with functional particles for the research of removing antibiotics from water bodies [94]. Wang et al. demonstrated the construction of drug libraries into core-shell nanofibers through modified triaxial electrospinning technology. Cellulose acetate (CA) was used as the polymer, the model drug acyclovir (ACY) prolonged the sustained release time during in vitro release study. The core-shell structure and uneven drug distribution make it show an excellent structure-performance relationship [95]. Therefore, core-shell nanofibers produced through coaxial and modified triaxial electrospinning techniques deliver various strategies for constructing new functional nanomaterials.

\subsubsection{Other Multifluid Electrospinning}

In multifluid electrospinning, in addition to the widely used core-shell structure and Janus structure, other multifluid electrospinning has also been carried out to study nanofibers with more complex structures. Correspondingly, processes such as quad-fluid coaxial electrospinning, trifluid side-by-side electrospinning and coaxial electrospinning with a side-by-side core have emerged [96]. Zhang et al. [97] reported a nanofiber system prepared by the quadriaxial electrospinning method. Gelatin was used to construct the second outermost and innermost layer, and polycaprolactone was used to build the second innermost and outermost layer. The antibacterial drug moxifloxacin (MXF) is loaded in different layers to achieve different controlled releases. This structure shows broad application prospects in tissue engineering.

\section{Electrospun Nanofibers in Wound Dressing}

Nanofibers prepared by electrospinning technology show excellent properties in promoting wound healing. Their microstructure is highly fitted to the human body ECM structure, which is conducive to cell growth, proliferation and adhesion $[31,98]$. At the same time, the high permeability and absorption rate can absorb the exudate formed on the wound surface and maintain a moist healing environment. In addition, the large surface area benefits loading and transporting bioactive ingredients such as drugs and growth factors $[34,99]$. Therefore, electrospun nanofiber materials are considered to be the ideal choice for wound dressings.

\subsection{Polymer in Electrospun Wound Dressing}

At present, there are hundreds of polymers that can be successfully used to prepare drug carriers by electrospinning. In related research on electrospinning wound dressings, both natural and synthetic polymers have been widely used. Figure 4 simply classifies and summarizes the common polymers in electrospun wound dressings. 


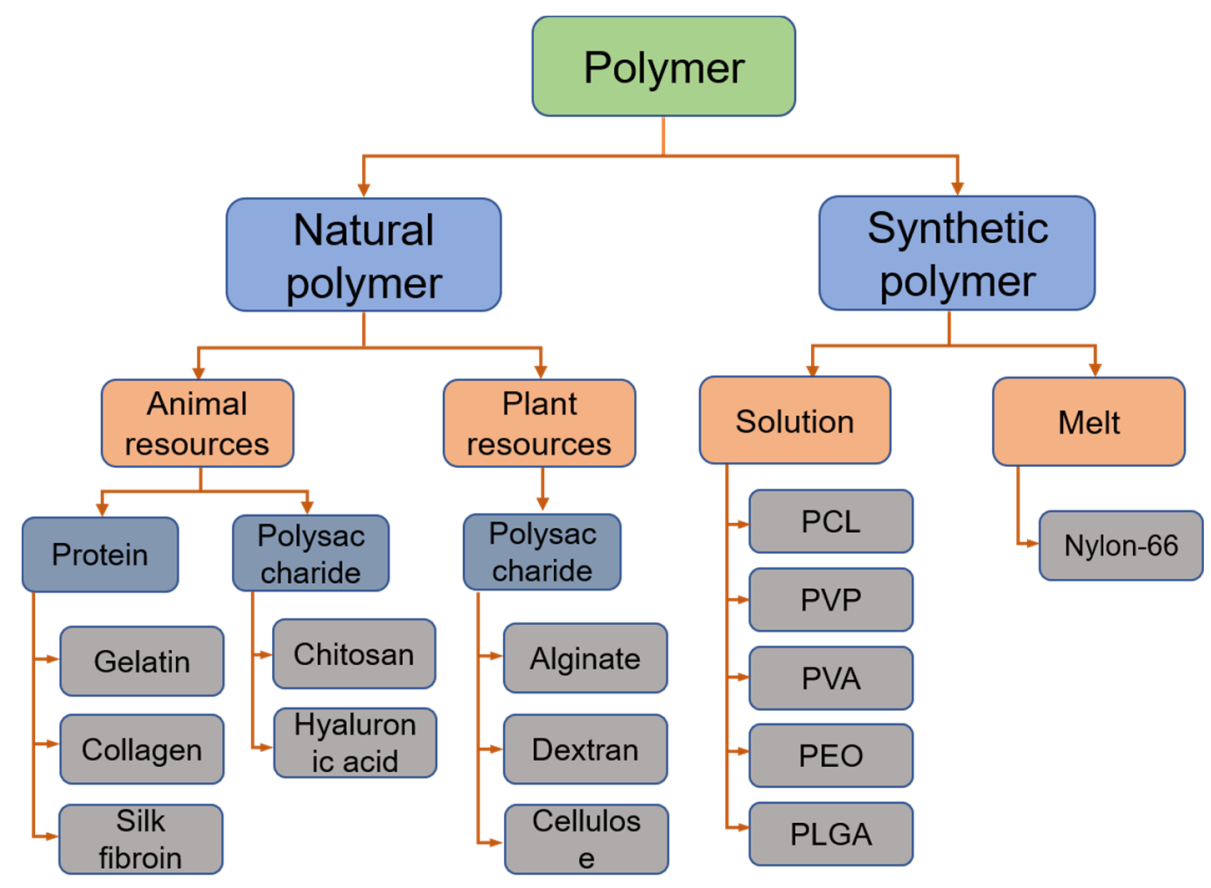

Figure 4. Common polymers used in electrospun wound dressings.

\subsubsection{Natural Polymer}

Natural polymers have non-toxic, biocompatibility and biodegradability properties, especially their own advantages such as antibacterial properties, making them popular in electrospinning wound dressings [100]. The following are several typical natural polymers that are used more frequently.

Gelatin, a natural protein biopolymer, is obtained by hydrolyzing part of collagen and is generally pale-yellow translucent particles or flakes. The products are abundant and cheap, and soluble in hot water, glycerin and acetic acid. It has good biocompatibility and biodegradability and is usually used in combination with synthetic polymer PCL to obtain better performance [101].

Chitosan (CS) is a derivative of chitin through deacetylation. It is a polysaccharide with a unique structure and superior functions [102]. It is soluble in aqueous solutions of organic acids such as formic acid and acetic acid, making them highly viscous and facilitating electrospinning [103]. Due to the amino activity on the backbone and the ductility of the hydroxyl group, it has potential applications in the fields of pharmacy, food packaging and wound treatment [104]. Figure 5A shows chitosan extracted from natural sources, developed into electrospun fiber membrane and its application in wound healing. Figure 5B shows a schematic diagram of the wound healing process of a drugloaded chitosan dressing, which is designed as a physical barrier to protect the wound from microbial invasion and support the migration and differentiation of fibroblasts. Xia et al. [105] used a simple one-step electrospinning method to prepare transparent chitosancoated cellulose membranes (CM-CS), and studied their cytotoxicity and antibacterial activity against Staphylococcus aureus (S. aureus) and Escherichia coli (E. coli). The wound healing effect was evaluated by constructing a wound healing model in mice.

Silk fibroin (SF) is a protein with a complex structure and has been used as a textile and sewing material for decades [106]. Many types of it can be obtained from bees, spiders, wasps, lacewings and silkworms (Figure 5C). Among them, SF extracted from silkworm cocoons is used in the field of biomedicine because of its outstanding mechanical properties, biocompatibility, biodegradability, flexibility, water vapor permeability and slight antibacterial properties. In particular, it has become an excellent candidate for wound dressing applications [107]. Hadisi et al. [108] used hyaluronic acid (HA) as the sheath spinning solution and $\mathrm{SF} /$ zinc oxide $(\mathrm{ZnO})$ as the core to prepare nanofibers with a 
core-sheath structure. The antibacterial mechanism of $\mathrm{ZnO}$ was explored through in vitro antibacterial tests, and the healing results of burn wounds in rats indicated that the dressing has a certain burn treatment effect (Figure 5D). Other natural polymer materials commonly used for electrospinning wound dressings include alginate [109], collagen and cellulose.

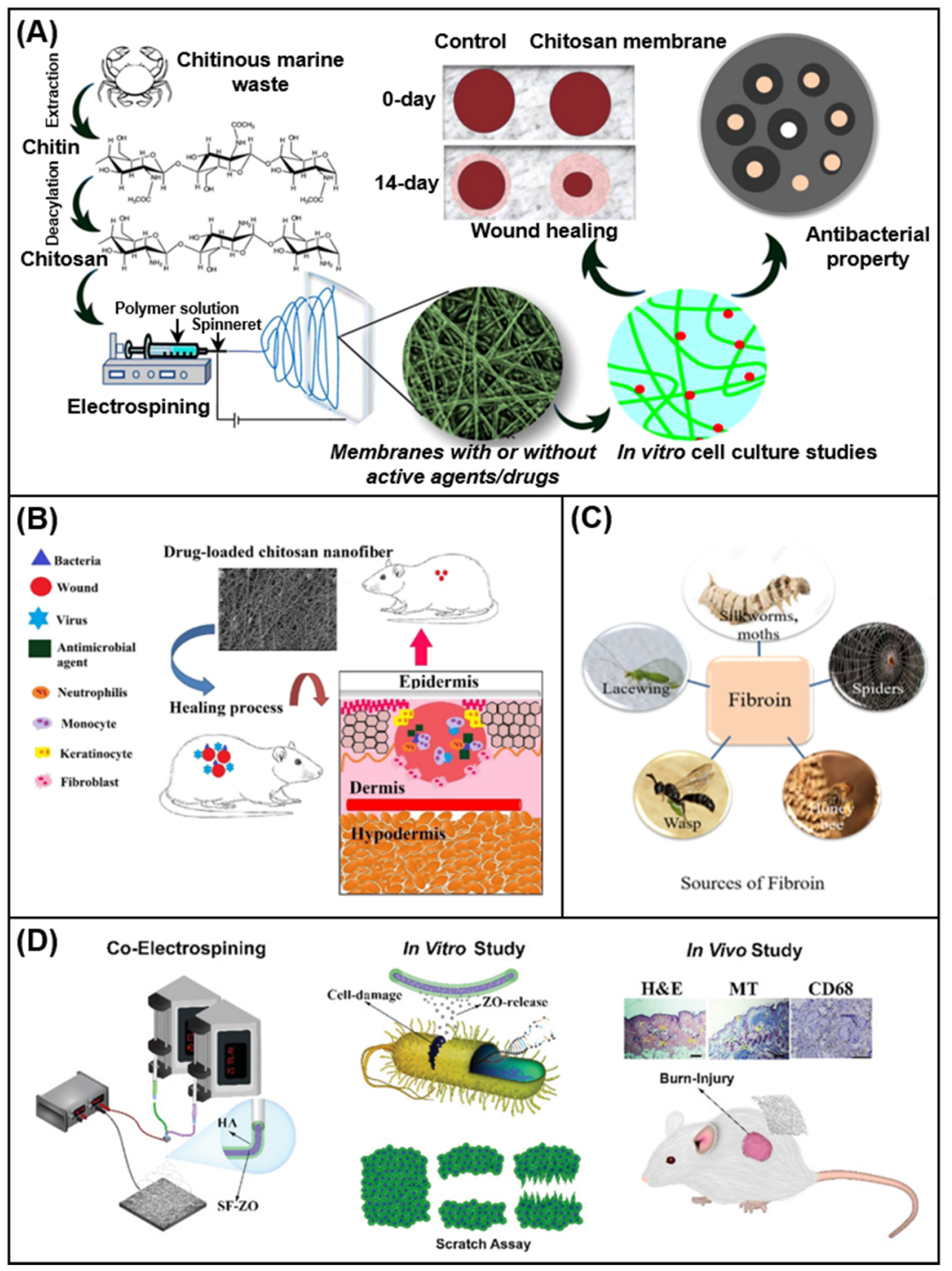

Figure 5. (A) Chitosan extracted from natural sources and developed into electrospun fiber membranes and its application in wound healing [34]; (B) a schematic diagram of the wound healing process of a drug-loaded chitosan dressing [103]; (C) the sources of fibroin [107]; (D) preparation and in vitro and in vivo study of HA/SF-ZO nanofiber by coaxial electrospinning [108].

\subsubsection{Synthetic Polymer}

There are more types of synthetic polymers applied in electrospinning than natural polymers, and related research on wound dressings is also abundant. Such polymers have excellent mechanical properties, thermal stability and spinnability, and are widely used as carrier materials for electrospinning wound dressings. The following summarizes several synthetic polymers that are more common in the research of wound dressings.

Polyvinylpyrrolidone (PVP) is a hydrophilic polymer prepared from the monomer vinylpyrrolidone (NVP) through bulk polymerization and solution polymerization. PVP is soluble in water and most organic solvents, and has low toxicity. Due to its excellent biocompatibility, it has been widely used in biomedicine and has become one of the three new drug dressings advocated internationally [110]. Chinatangkul et al. [111] mixed 
shellac (SHL) with PVP, added Monolaurin (ML) and prepared nanofibers by blending electrospinning technology. It shows excellent inhibitory activity against $S$. aureus and Candida albicans, indicating that the electrospun nanofiber is suitable for wound treatment.

PCL is a polymer obtained by ring-opening polymerization of $\varepsilon$-caprolactone, which is a material approved by the FDA. It is a white particle and exists in a semi-crystalline state with a low melting point. Because of its outstanding spinnability and mechanical strength, is being widely applied in wound dressings [112]. He et al. [113] prepared a series of nanofibers with antibacterial, anti-oxidation, tensile properties and electrical activity by electrospinning PCL and CS-grafted polyaniline (QCSP) polymer solution (Figure 6A). In the mouse full-thickness wound defect model, the wound healing process is significantly accelerated, showing broad application prospects.

PVA is a white and odorless polymer. It is soluble in water above $95^{\circ} \mathrm{C}$. In addition to being an important chemical raw material, PVA has also drawn in much consideration in the field of medicine. At present, it has a broad scope of utilizations in artificial joints and wound dressings [114]. Ali et al. [115] used a PVA solution to prepare nanofiber mats with Nigella sativa extract deposited by electrospinning. Wound healing analysis results show that the developed PVA-Nigella sativa nanofibrous mat has good wound healing properties and a short recovery time.

\subsubsection{Combination of Natural and Synthetic Polymers}

On the basis of the benefits of easy degradation and excellent biocompatibility of natural polymers, and the controllability and reliable mechanical strength of synthetic polymers, combining the two types of fibers is the choice of many researchers [116]. Ramalingam et al. [117] reported using PCL/gelatin as a polymer carrier to prepare a coaxial electrospun core-sheath nanofiber membrane, containing antibiotic minocycline and herbal extracts as a multifunctional scaffold for the treatment of secondary burns. The core-sheath structure maintains the sustained release of biologically active ingredients. In addition to showing strong antibacterial activity, it also promotes the proliferation and diffusion of skin cells. Improved collagen tissue can be observed through the second-degree burn model of pigskin. Figure $6 \mathrm{~B}$ shows the excellent properties of the prepared PCL/gelatin core-sheath structure mat. Zou et al. [118] reported the preparation of PVA/CS nanofibers with carboxymethyl CS nanoparticles, which encapsulated the antimicrobial peptide $\mathrm{OH}$ CATH30. Results showed that prepared nanofibers contain antibacterial properties and can promote wound healing. Khan et al. [119] successfully encapsulated oregano oil in Poly (L-lactide-co-caprolactone) (PLCL)/SF nanofiber membranes. Cytotoxicity and antibacterial tests showed high biocompatibility and antibacterial activity, respectively. At the same time, it can also improve the quality of wound healing and could be used as a potential wound dressing.

\subsection{Bioactive Ingredients in Electrospun Wound Dressing}

Another important advantage of electrospinning to prepare nanofiber wound dressings is that it can load a variety of biologically active ingredients to prepare functionalized products. At present, to improve the antibacterial properties of dressings, commonly used active substances include antibiotic drugs (ciprofloxacin (CIP), curcumin, metronidazole, tetracycline, gentamicin and diclofenac), inorganic nanoparticles (nanosilver particles (AgNP), $\mathrm{ZnO}$, titanium dioxide $\left(\mathrm{TiO}_{2}\right)$, cerium oxide $\left.\left(\mathrm{CeO}_{2}\right)\right)$, natural substances (honey, essential oils, chitosan) and growth factors [120-123]. 


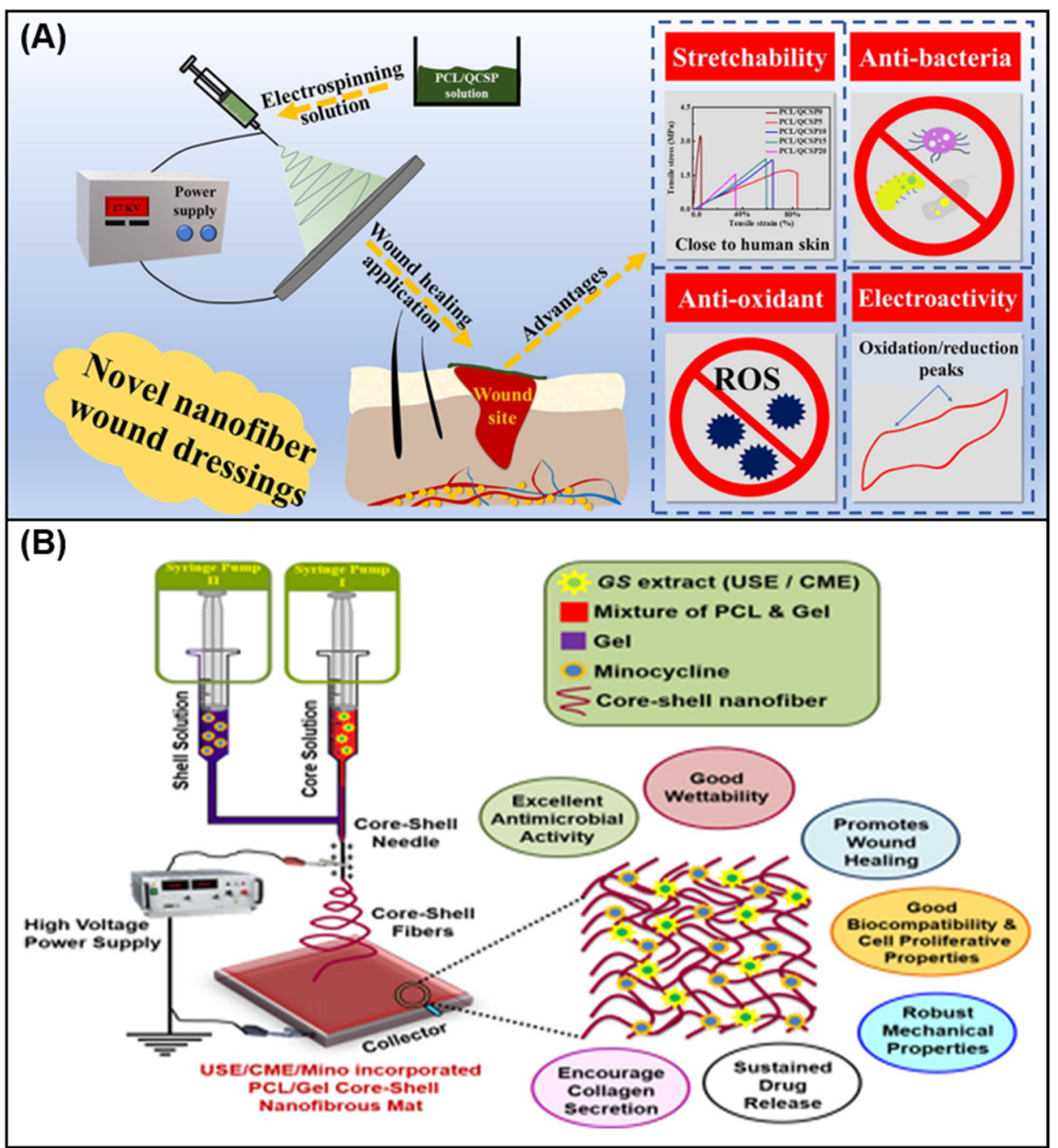

Figure 6. (A) Electrospinning PCL/QCSP nanofiber membrane with anti-bacteria, anti-oxidant, stretchability and electroactivity [113]; (B) preparation of coaxial electrospinning nanofiber mat and its excellent properties [117].

Augustine et al. [124] reported the development of a new type of $\mathrm{nCeO}_{2}$, which contains electrospun poly (3-hydroxybutyrate-co-3-hydroxy valerate) (PHBV) membrane. In vivo wound healing studies in diabetic rats confirmed that PHBV membranes mixed with $1 \% \mathrm{nCeO}_{2}$ showed perfect cell compatibility, and could be used as promising biomaterials to treat diabetic wound healing (Figure 7A). Yang et al. [125] used the side-by-side electrospinning process to prepare Janus nanofibers containing CIP and AgNP as the polymer matrix, and studied their effects on wound healing. The antibacterial effect in the process provides a new idea for the preparation of new antibacterial wound dressings. Jafari et al. [126] prepared a bilayer nanofiber scaffold based on PCL and gelatin. The top layer contains amoxicillin, and the bottom layer contains $\mathrm{n}-\mathrm{ZnO}$ to accelerate wound healing. In vitro release test showed the sustained release of amoxicillin. Analysis of wound healing in rats showed that the scaffold improved the shrinkage rate of the wound, enhanced the deposition of collagen and reduced the formation of scars. All results and findings indicate that prefabricated stents can be a promising alternative method for treating skin injuries. Figure $7 \mathrm{~B}$ shows the characterization analysis of the prepared bilayer nanofiber scaffold. Table 2 summarizes the common polymers and active substances in electrospinning wound dressings. 


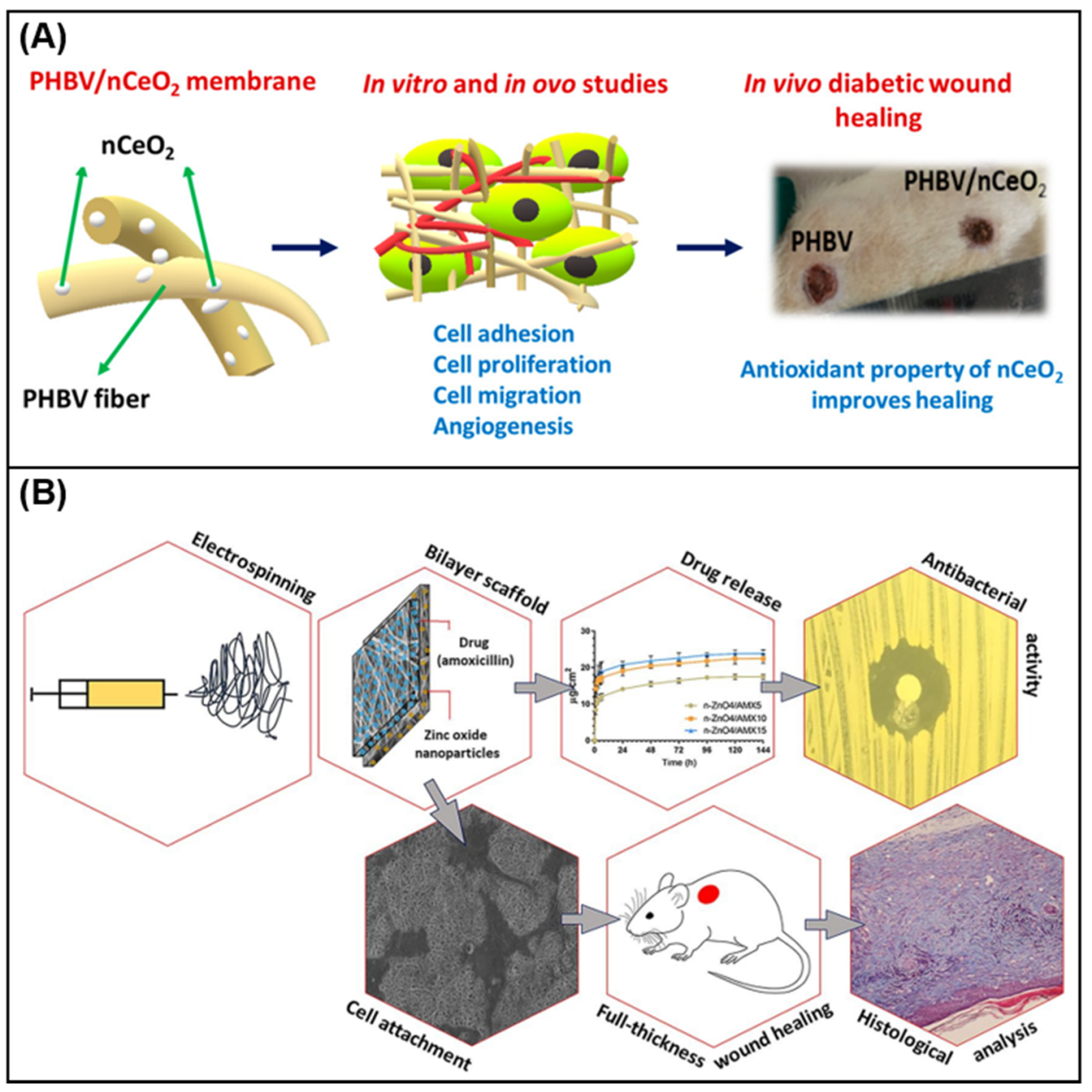

Figure 7. (A) $\mathrm{PHBV} / \mathrm{nCeO}_{2}$ nanofiber membrane in cell adhesion, migration and wound healing research [124]; (B) the electrospun antibacterial bilayer nanofiber scaffold is used to promote the various characterization analysis of the full-thickness skin defect healing in mice [126].

Table 2. The latest literature on polymer materials and bioactive ingredients used in electrospinning to promote skin wound healing.

\begin{tabular}{|c|c|c|c|c|c|c|}
\hline $\begin{array}{l}\text { Scaffold } \\
\text { Material }\end{array}$ & $\begin{array}{c}\text { Additional } \\
\text { Polymer }\end{array}$ & $\begin{array}{l}\text { Bioactive } \\
\text { Ingredients }\end{array}$ & Solvent & $\begin{array}{l}\text { Electrospinning } \\
\text { Technique }\end{array}$ & Highlights & Ref. \\
\hline \multirow{2}{*}{ Gelatin } & CA & Berberine & HFP & Blend & $\begin{array}{l}\text { Has strong antibacterial activity and is } \\
\text { suitable for the management and } \\
\text { treatment of diabetic foot ulcer }\end{array}$ & [127] \\
\hline & CA/PVP & Gentamicin & $\begin{array}{l}\text { Acetic acid, } \\
\text { ethanol }\end{array}$ & Bi-layer & $\begin{array}{l}\text { Thermal stability, wettability } \\
\text { characteristics and antibacterial activity }\end{array}$ & [128] \\
\hline \multirow[t]{2}{*}{ Collagen } & EC/PLA & $\begin{array}{l}\text { Silver } \\
\text { sulfadiazine }\end{array}$ & $\begin{array}{l}\text { Chloroform, } \\
\text { ethanol }\end{array}$ & Blend & $\begin{array}{l}\text { The antibacterial performance showed } \\
\text { inhibitory activity against Bacillus }(9.71 \\
\pm 1.15 \mathrm{~mm}) \text { and E. coli }(12.46 \pm 1.31 \mathrm{~mm}), \\
\text { promoted cell proliferation and adhesion }\end{array}$ & [129] \\
\hline & Zein/PCL & $\mathrm{n}-\mathrm{ZnO}$, aloe vera & $\begin{array}{l}\text { Chloroform, } \\
\text { ethanol }\end{array}$ & Blend & $\begin{array}{l}\text { The developed nanofibers revealed good } \\
\text { cell compatibility }\end{array}$ & [130] \\
\hline \multirow[t]{2}{*}{ CS } & PCL & $\begin{array}{l}\text { Lidocaine } \\
\text { hydrochloride, } \\
\text { mupirocin }\end{array}$ & HFIP, DCM & Dual & $\begin{array}{c}\text { Have the functions of promoting } \\
\text { hemostasis, antibacterial, and } \\
\text { drug release. }\end{array}$ & [131] \\
\hline & $\mathrm{PEO} / \mathrm{CNC}$ & Acacia extract & Acetic acid & Blend & $\begin{array}{c}\text { A continuous release of natural acacia } \\
\text { extract from nanofibers occurred } \\
\text { during } 24 \mathrm{~h}\end{array}$ & [132] \\
\hline
\end{tabular}


Table 2. Cont

\begin{tabular}{|c|c|c|c|c|c|c|}
\hline $\begin{array}{l}\text { Scaffold } \\
\text { Material }\end{array}$ & $\begin{array}{l}\text { Additional } \\
\text { Polymer }\end{array}$ & $\begin{array}{l}\text { Bioactive } \\
\text { Ingredients }\end{array}$ & Solvent & $\begin{array}{l}\text { Electrospinning } \\
\text { Technique }\end{array}$ & Highlights & Ref. \\
\hline \multirow[t]{2}{*}{ SF } & PLGA & Artemisinin & HFIP & Blend & $\begin{array}{l}\text { The fabricated membrane shows } \\
\text { anti-inflammatory properties } \\
\text { without cytotoxicity }\end{array}$ & [133] \\
\hline & PCL/PVA & Curcumin & $\begin{array}{l}\text { Formic acid, } \\
\text { dichloromethane }\end{array}$ & Blend & $\begin{array}{l}\text { Accelerate wound healing in } \\
\text { diabetic mice }\end{array}$ & {$[134]$} \\
\hline \multirow[t]{2}{*}{ Alginate } & PVA/CS & Dexpanthenol & Acetic acid & Coaxial & $\begin{array}{l}\text { Not only is it non-toxic to fibroblasts, but } \\
\text { it also has a certain effect on cell } \\
\text { attachment and morphology }\end{array}$ & [135] \\
\hline & PVA & $\begin{array}{l}\text { Cardamom } \\
\text { extract }\end{array}$ & Distilled water & Blend & $\begin{array}{l}\text { Have good biocompatibility and } \\
\text { antibacterial properties }\end{array}$ & [136] \\
\hline \multirow[b]{2}{*}{ PVP } & $\mathrm{EC}$ & CIP, AgNP & $\begin{array}{l}\text { Ethanol, acetic } \\
\text { acid, acetone }\end{array}$ & Side-by-side & Janus fiber has good bactericidal activity & [125] \\
\hline & PLA/PEO/Collagen & Cefazolin & $\begin{array}{l}\text { DCM, DMF, } \\
\text { HFIP, ethanol }\end{array}$ & Coaxial & $\begin{array}{l}\text { Antibacterial studies on wounds show } \\
\text { that they can effectively inhibit the } \\
\text { growth of microorganisms. }\end{array}$ & [137] \\
\hline \multirow{5}{*}{ PCL } & CS & Aloe vera & Acetic acid & Blend & $\begin{array}{l}\text { Have good antibacterial properties and } \\
\text { biocompatibility }\end{array}$ & [138] \\
\hline & CS & Curcumin & $\begin{array}{l}\text { Ethanol, acetic } \\
\text { acid }\end{array}$ & Blend & $\begin{array}{l}\text { Shows antibacterial, anti-oxidant and } \\
\text { wound healing capabilities }\end{array}$ & [139] \\
\hline & Gelatin & Oregano oil & HFIP & Blend & $\begin{array}{l}\text { Good biocompatibility and } \\
\text { antibacterial activity }\end{array}$ & [140] \\
\hline & / & $\begin{array}{l}\text { Urtica dioica, } \\
\mathrm{n}-\mathrm{ZnO}\end{array}$ & DMF, DCM & Blend & $\begin{array}{l}\text { The hybrid scaffold shows high } \\
\text { antibacterial activity and cell viability }\end{array}$ & [141] \\
\hline & Gelatin & Clove essential oil & $\begin{array}{l}\text { Glacial acetic } \\
\text { acid }\end{array}$ & Blend & Antibacterial activity & [142] \\
\hline \multirow{2}{*}{ PVA } & CS/Starch & / & $\begin{array}{l}\text { Double- } \\
\text { distilled water, } \\
\text { acetic acid }\end{array}$ & Blend & $\begin{array}{l}\text { Proper tensile strength and elongation, } \\
\text { excellent biocompatibility and } \\
\text { antibacterial activity }\end{array}$ & [143] \\
\hline & CS & / & Acetic acid & Blend & $\begin{array}{c}\text { Good physical and chemical properties, } \\
\text { biocompatibility and } \\
\text { antibacterial properties }\end{array}$ & [144] \\
\hline \multirow[b]{2}{*}{$\mathrm{PEO}$} & CS & Vancomycin & Acetic acid & Blend & Antibacterial effects against $S$. aureus & {$[145]$} \\
\hline & CS & Teicoplanin & Acetic acid & Dual & $\begin{array}{l}\text { Wound closure was } \\
\text { significantly improved }\end{array}$ & [146] \\
\hline
\end{tabular}

HFP: Hexafluoropropylene, EC: Ethylcellulose, PLA: Polylactic acid, HFIP: 1,1,1,3,3,3-hexafluoro-2-propanol, DCM: Dichloromethane, PEO: Polyethene oxide, CNC: Cellulose nanocrystals, DMF: N,N-dimethylformamide.

\subsection{In Situ Electrospinning in Wound Dressing}

Compared with ordinary electrospinning, in situ electrospinning is more convenient and comfortable to use, and can better cover wounds. Simultaneously, dressings can be customized according to patient needs [147]. Qin et al. [148] used a portable electrospinning device to prepare electrospun Zein/Clove essential oil nanofiber. In vitro experiments have observed good biocompatibility and antibacterial effects. In the mouse wound model, it can be observed that the prepared Zein/CEO nanofiber membrane promotes wound healing. Figure 8A shows the diagram of its preparation. Yue et al. [149] used ethanolsoluble polyurethane (EPU) and Fluorinated polyurethane (FPU) as polymer carriers and used a customized electrospinning device to prepare thymol-loaded nanofiber membranes (Figure 8B(a)). The results indicate that the membrane has good breathable, waterproof performance and excellent antibacterial activity (Figure $8 \mathrm{~B}(\mathrm{~b})$ ), providing a promising strategy for developing portable electrospinning devices. 


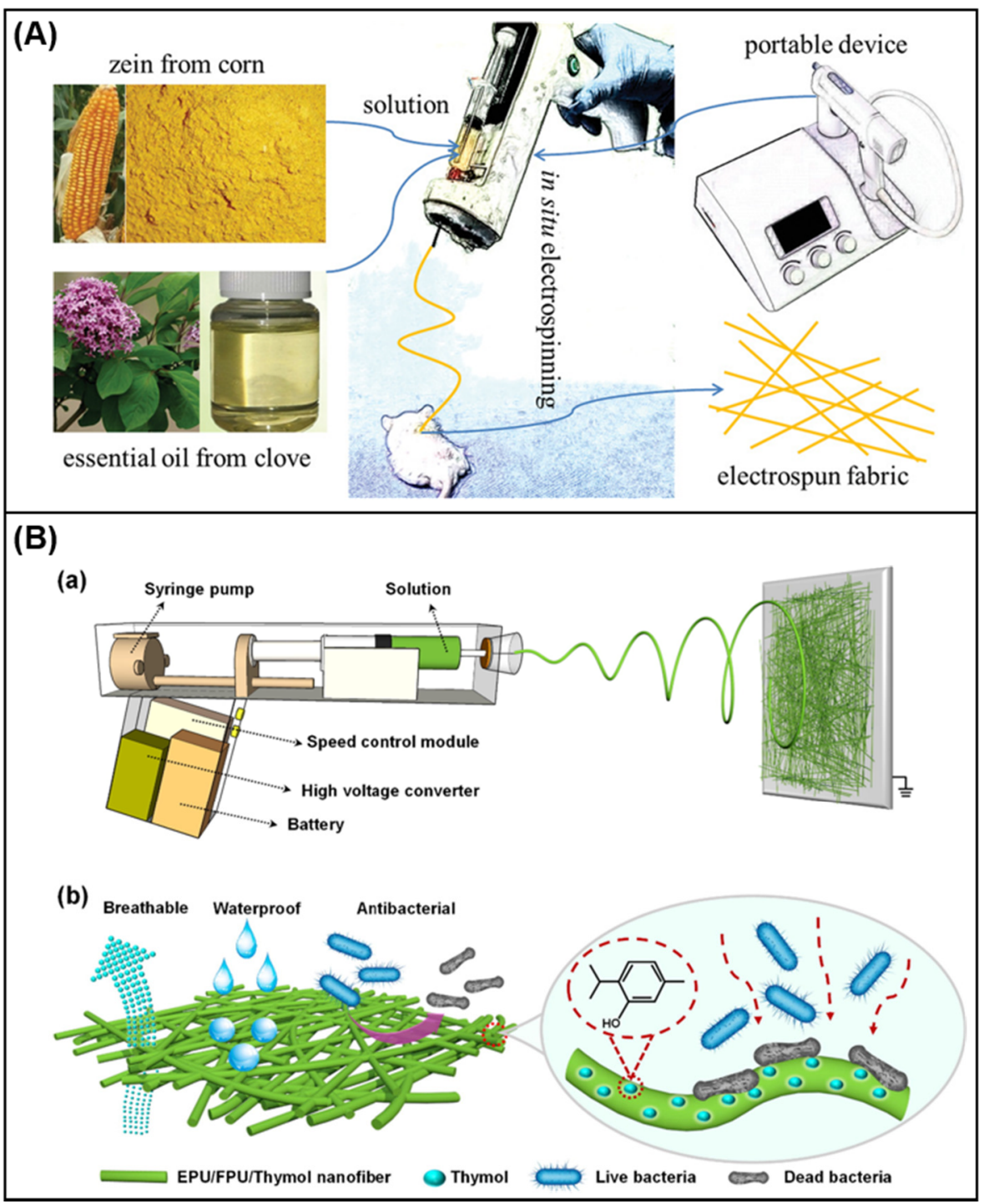

Figure 8. (A) In situ electrospinning process [148]; (B) [149] (a) schematic diagram of portable electrospinning device and preparation of EPU/FPU/thymol nanofiber; (b) schematic diagram of the breathable, waterproof and antibacterial functions of EPU/FPU/Thymol nanofiber.

\subsection{Application of Electrospinning Technology in Other Fields}

In recent years, the advantages of electrospinning have attracted more and more attention. With the continuous research of related scholars, the application of electrospinning nanofibers has become more and more extensive. In addition to playing a role in the field of biomedicine (drug delivery [150-152], tissue engineering [153] and wound dressings), it also plays a pivotal position in environmental protection (air filtration, water treatment), energy and chemical industries (light-emitting device, solar cell and supercapacitor) and other fields $[154,155]$. Fiber materials with unique structures and characteristics arranged by electrospinning have been generally utilized in different fields (Figure 9). Combining the structural advantages of the materials with the properties of the materials will be the focus of future research. 


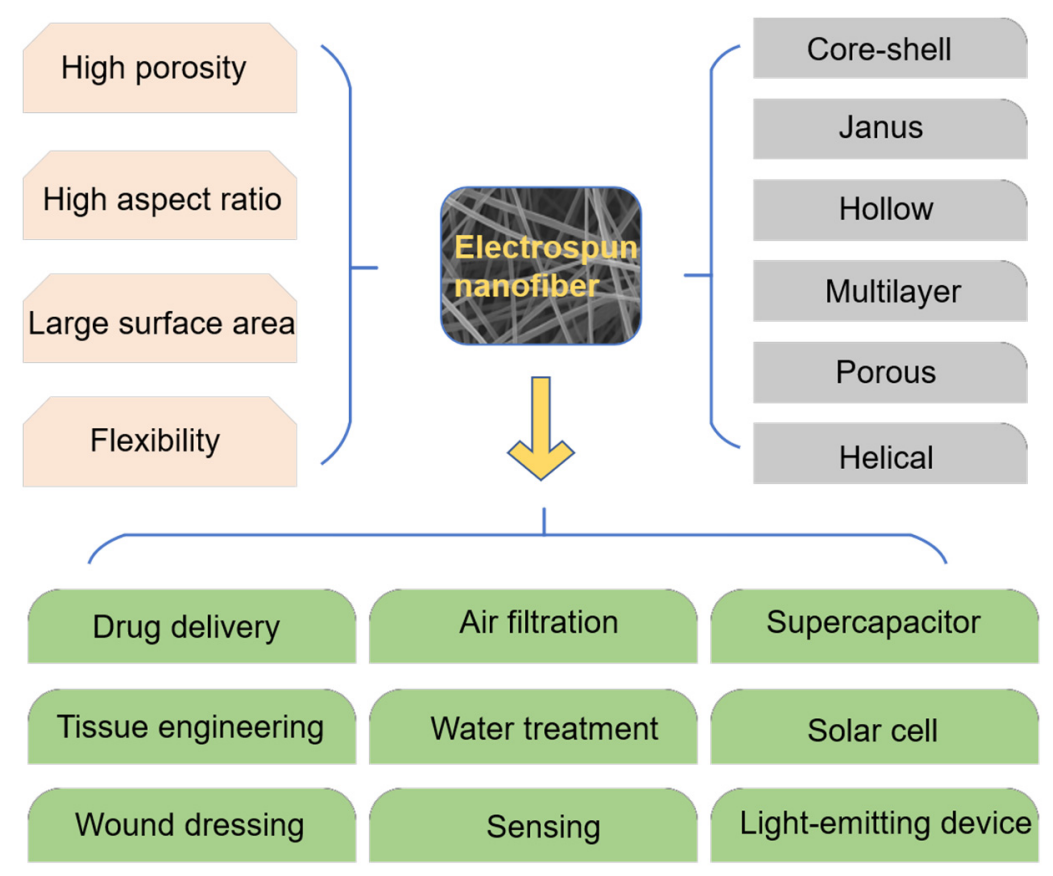

Figure 9. Structure, performance and application of electrospun nanofiber.

\section{Conclusions and Future Perspectives}

Electrospinning technology has attracted more and more attention in recent years as a highly versatile technology for preparing micro-nano-level fibers with diameters. Electrospinning fiber material has an extremely high specific surface area, high porosity, adjustable fiber morphology and surface function. These characteristics make the electrospun fiber material possess a series of ideal properties, which can meet the application requirements of various fields such as biomedicine and tissue engineering. With the development of coaxial electrospinning, side-by-side electrospinning and triaxial electrospinning, highquality nanofibers with core-sheath structure, Janus structure and triaxial structure have been prepared. In the future, more advanced and complex multi-fluid electrospinning technology can be utilized to produce nanofibers with new structures. At the same time, electrospun nanofibers can carry a variety of active substances and have the ability to continuously release drugs and nanoparticles, which is highly beneficial for improving the overall performance of the wound.

The development of wound dressings still faces some challenges that need to be considered, and many researchers have also given different views. Different wound exudates are extremely different, which makes it difficult to find the ideal dressing for all wound types $[49,121]$. Therefore, the bioactive nanofiber dressing produced by electrospinning technology takes into account the characteristics of the wound healing process, stimulates cell migration, and controls inflammation. At the same time, it relieves pain by releasing related drugs, and can be effectively used for acute or chronic wound treatment. However, this advanced dressing needs to be evaluated in a large number of clinical trials to ensure the final clinical application. We believe that our review provides insights and references for the further development of electrospun nanofibers in clinical applications. In the future, it is necessary to improve the performance of electrospun fibers further, realize the standardization of drug-loaded fiber preparation methods, and prepare new functional wound dressings to provide more technical support for biomedical applications.

Author Contributions: Conceptualization, methodology, X.L.; validation, formal analysis; writing —original draft preparation, H.X.; writing - review and editing, M.Z.; supervision, project administration, D.-G.Y. All authors have read and agreed to the published version of the manuscript. 
Funding: This research was funded by joint project of USST-CIHE (No. 20181116) and Natural Science Foundation of Shanghai (No. 20ZR1439000).

Institutional Review Board Statement: Not applicable.

Informed Consent Statement: Not applicable.

Data Availability Statement: The data supporting the findings of this manuscript are available from the corresponding authors upon reasonable request.

Conflicts of Interest: The authors declare no conflict of interest.

\section{References}

1. Nosrati, H.; Aramideh Khouy, R.; Nosrati, A.; Khodaei, M.; Banitalebi-Dehkordi, M.; Ashrafi-Dehkordi, K.; Sanami, S.; Alizadeh, Z. Nanocomposite scaffolds for accelerating chronic wound healing by enhancing angiogenesis. J. Nanobiotechnology 2021, 19, 1-22. [CrossRef] [PubMed]

2. Fatehi, P.; Abbasi, M. Medicinal plants used in wound dressings made of electrospun nanofibers. J. Tissue Eng. Regen. Med. 2020, 14, 1527-1548. [CrossRef]

3. El Ayadi, A.; Jay, J.W.; Prasai, A. Current approaches targeting the wound healing phases to attenuate fibrosis and scarring. Int. J. Mol. Sci. 2020, 21, 1105. [CrossRef] [PubMed]

4. Chen, M.; Tian, J.; Liu, Y.; Cao, H.; Li, R.; Wang, J.; Wu, J.; Zhang, Q. Dynamic covalent constructed self-healing hydrogel for sequential delivery of antibacterial agent and growth factor in wound healing. Chem. Eng. J. 2019, 373, 413-424. [CrossRef]

5. Chen, K.; Wang, F.; Liu, S.; Wu, X.; Xu, L.; Zhang, D. In situ reduction of silver nanoparticles by sodium alginate to obtain silver-loaded composite wound dressing with enhanced mechanical and antimicrobial property. Int. J. Biol. Macromol. 2020, 148, 501-509. [CrossRef] [PubMed]

6. Fahimirad, S.; Ajalloueian, F. Naturally-derived electrospun wound dressings for target delivery of bioactive agents. Int. J. Pharm. 2019, 566, 307-328. [CrossRef] [PubMed]

7. Kanikireddy, V.; Varaprasad, K.; Jayaramudu, T.; Karthikeyan, C.; Sadiku, R. Carboxymethyl cellulose-based materials for infection control and wound healing: A review. Int. J. Biol. Macromol. 2020, 164, 963-975. [CrossRef]

8. Das, A.; Uppaluri, R.; Das, C. Feasibility of poly-vinyl alcohol/starch/glycerol/citric acid composite films for wound dressing applications. Int. J. Biol. Macromol. 2019, 131, 998-1007. [CrossRef]

9. Weng, W.; Chi, J.; Yu, Y.; Zhang, C.; Shi, K.; Zhao, Y. Multifunctional composite inverse opal film with multiactives for wound healing. ACS Appl. Mater. Interfaces 2021, 13, 4567-4573. [CrossRef] [PubMed]

10. Bužarovska, A.; Dinescu, S.; Lazar, A.D.; Serban, M.; Pircalabioru, G.G.; Costache, M.; Gualandi, C.; Avérous, L. Nanocomposite foams based on flexible biobased thermoplastic polyurethane and $\mathrm{ZnO}$ nanoparticles as potential wound dressing materials. Mater. Sci. Eng. C 2019, 104, 109893. [CrossRef]

11. Cui, H.; Liu, M.; Yu, W.; Cao, Y.; Zhou, H.; Yin, J.; Liu, H.; Que, S.; Wang, J.; Huang, C.; et al. Copper peroxide-loaded gelatin sponges for wound dressings with antimicrobial and accelerating healing properties. ACS Appl. Mater. Interfaces 2021, 13, $26800-26807$. [CrossRef] [PubMed]

12. Zhao, X.; Pei, D.; Yang, Y.; Xu, K.; Yu, J.; Zhang, Y.; Zhang, Q.; He, G.; Zhang, Y.; Li, A.; et al. Green tea derivative driven smart hydrogels with desired functions for chronic diabetic wound treatment. Adv. Funct. Mater. 2021, 31, 2009442. [CrossRef]

13. Pan, X.; Kong, D.; Wang, W.; Liu, W.; Ou-Yang, W.; Zhang, C.; Wang, Q.; Huang, P.; Zhang, C.; Li, Y. Synthetic polymeric antibacterial hydrogel for methicillin-resistant staphylococcus aureus-infected wound healing: Nanoantimicrobial self-assembly, drug- and cytokine-free strategy. ACS Nano 2020, 14, 12905-12917.

14. Chen, L.; Zhang, L.; Zhang, H.; Sun, X.; Liu, D.; Zhang, J.; Zhang, Y.; Cheng, L.; Santos, H.A.; Cui, W. Programmable immune activating electrospun fibers for skin regeneration. Bioact. Mater. 2021, 6, 3218-3230. [CrossRef]

15. Guo, X.; Liu, Y.; Bera, H.; Zhang, H.; Chen, Y.; Cun, D.; Foderà, V.; Yang, M. $\alpha$-Lactalbumin-based nanofiber dressings improve burn wound healing and reduce scarring. ACS Appl. Mater. Interfaces 2020, 12, 45702-45713. [CrossRef]

16. Toriello, M.; Afsari, M.; Shon, H.K.; Tijing, L.D. Progress on the fabrication and application of electrospun nanofiber composites. Membranes 2020, 10, 1-35. [CrossRef]

17. Akhmetova, A.; Heinz, A. Electrospinning proteins for wound healing purposes: Opportunities and challenges. Pharmaceutics 2021, 13, 1-22.

18. Jao, D.; Beachley, V.Z. Continuous dual-track fabrication of polymer micro-/nanofibers based on direct drawing. ACS Macro Lett. 2019, 8, 588-595. [CrossRef]

19. Shin, S.; Menk, F.; Kim, Y.; Lim, J.; Char, K.; Zentel, R.; Choi, T.L. Living light-induced crystallization-driven self-assembly for rapid preparation of semiconducting nanofibers. J. Am. Chem. Soc. 2018, 140, 6088-6094. [CrossRef]

20. Qin, W.; Li, J.; Tu, J.; Yang, H.; Chen, Q.; Liu, H. Fabrication of porous chitosan membranes composed of nanofibers by low temperature thermally induced phase separation, and their adsorption behavior for $\mathrm{Cu}^{2+}$. Carbohydr. Polym. 2017, 178, 338-346. [CrossRef] 
21. Kamin, Z.; Abdulrahim, N.; Misson, M.; Chiam, C.K.; Sarbatly, R.; Krishnaiah, D.; Bono, A. Use of melt blown polypropylene nanofiber templates to obtain homogenous pore channels in glycidyl methacrylate/ethyl dimethacrylate-based monoliths. Chem. Eng. Commun. 2021, 208, 661-672. [CrossRef]

22. Bazmandeh, A.Z.; Mirzaei, E.; Fadaie, M.; Shirian, S.; Ghasemi, Y. Dual spinneret electrospun nanofibrous/gel structure of chitosan-hyaluronic acid as a wound dressing: In-vitro and in-vivo studies. Int. J. Biol. Macromol. 2020, 162, 359-373. [CrossRef]

23. Sabra, S.; Ragab, D.M.; Agwa, M.M.; Rohani, S. Recent advances in electrospun nanofibers for some biomedical applications. Eur. J. Pharm. Sci. 2020, 144, 105224. [CrossRef]

24. Abazari, M.F.; Nasiri, N.; Nejati, F.; Kohandani, M.; Hajati-Birgani, N.; Sadeghi, S.; Piri, P.; Soleimanifar, F.; Rezaei-Tavirani, M.; Mansouri, V. Acceleration of osteogenic differentiation by sustained release of BMP2 in PLLA/graphene oxide nanofibrous scaffold. Polym. Adv. Technol. 2021, 32, 272-281. [CrossRef]

25. Mozaffari, A.; Gashti, M.P.; Mirjalili, M.; Parsania, M. Argon and argon-oxygen plasma surface modification of gelatin nanofibers for tissue engineering applications. Membranes 2021, 11, 1-13. [CrossRef]

26. Luraghi, A.; Peri, F.; Moroni, L. Electrospinning for drug delivery applications: A review. J. Control. Release 2021, $334,463-484$. [CrossRef] [PubMed]

27. Li, Z.; Wen, W.; Chen, X.; Zhu, L.; Cheng, G.; Liao, Z.; Huang, H.; Ming, L. Release characteristics of an essential oil component encapsulated with cyclodextrin shell matrices. Curr. Drug Deliv. 2021, 18, 487-499. [CrossRef] [PubMed]

28. Yu, D.G. Preface-bettering drug delivery knowledge from pharmaceutical techniques and excipients. Curr. Drug Deliv. 2021, 18, 2-3. [CrossRef]

29. Schuhladen, K.; Raghu, S.N.V.; Liverani, L.; Neščáková, Z.; Boccaccini, A.R. Production of a novel poly(ع-caprolactone)methylcellulose electrospun wound dressing by incorporating bioactive glass and Manuka honey. J. Biomed. Mater. Res. Part B 2021, 109, 180-192. [CrossRef]

30. Bootdee, K.; Nithitanakul, M. Poly (d, l-lactide-co-glycolide) nanospheres within composite poly (vinyl alcohol)/aloe vera electrospun nanofiber as a novel wound dressing for controlled release of drug. Int. J. Polym. Mater. Polym. Biomater. 2021, 70, 223-230. [CrossRef]

31. Lan, X.; Liu, Y.; Wang, Y.; Tian, F.; Miao, X.; Wang, H.; Tang, Y. Coaxial electrospun PVA/PCL nanofibers with dual release of tea polyphenols and $\varepsilon$-poly(L-lysine) as antioxidant and antibacterial wound dressing materials. Int. J. Pharm. 2021, 601, 120525. [CrossRef] [PubMed]

32. Bonferoni, M.C.; Rossi, S.; Sandri, G.; Caramella, C.; Del Fante, C.; Perotti, C.; Miele, D.; Vigani, B.; Ferrari, F. Bioactive medications for the delivery of platelet derivatives to skin wounds. Curr. Drug Deliv. 2019, 16, 472-483. [CrossRef] [PubMed]

33. Keshvardoostchokami, M.; Majidi, S.S.; Huo, P.; Ramachandran, R.; Chen, M.; Liu, B. Electrospun nanofibers of natural and synthetic polymers as artificial extracellular matrix for tissue engineering. Nanomaterials 2021, 11, 1-23.

34. Augustine, R.; Rehman, S.R.U.; Ahmed, R.; Zahid, A.A.; Sharifi, M.; Falahati, M.; Hasan, A. Electrospun chitosan membranes containing bioactive and therapeutic agents for enhanced wound healing. Int. J. Biol. Macromol. 2020, 156, 153-170. [CrossRef] [PubMed]

35. Ather, S.; Harding, K.G.; Tate, S.J. Wound management and dressings. In Advanced Textiles for Wound Care, 2nd ed.; The Textile Institute Book Series; Woodhead Publishing: Cambridge, UK, 2019; pp. 1-22.

36. Wang, W.; Lu, K.J.; Yu, C.H.; Huang, Q.L.; Du, Y.Z. Nano-drug delivery systems in wound treatment and skin regeneration. J. Nanobiotechnology 2019, 17, 1-15. [CrossRef]

37. Iacob, A.T.; Drăgan, M.; Ionescu, O.M.; Profire, L.; Ficai, A.; Andronescu, E.; Confederat, L.G.; Lupascu, D. An overview of biopolymeric electrospun nanofibers based on polysaccharides for wound healing management. Pharmaceutics 2020, 12, 1-49. [CrossRef] [PubMed]

38. Tottoli, E.M.; Dorati, R.; Genta, I.; Chiesa, E.; Pisani, S.; Conti, B. Skin wound healing process and new emerging technologies for skin wound care and regeneration. Pharmaceutics 2020, 12, 1-30. [CrossRef]

39. Wang, Y.; Feng, Q.; Li, Z.; Bai, X.; Wu, Y.; Liu, Y. Evaluating the effect of integra seeded with adipose tissue-derived stem cells or fibroblasts in wound healing. Curr. Drug Deliv. 2020, 17, 629-635. [CrossRef]

40. Smet, S.; Probst, S.; Holloway, S.; Fourie, A.; Beele, H.; Beeckman, D. The measurement properties of assessment tools for chronic wounds: A systematic review. Int. J. Nurs. Stud. 2021, 121, 103998. [CrossRef]

41. Sen, C.K. Human wounds and its burden: An updated compendium of estimates. Adv. Wound Care 2019, 8, 39-48. [CrossRef]

42. Homaeigohar, S.; Boccaccini, A.R. Antibacterial biohybrid nanofibers for wound dressings. Acta Biomater. 2020, 107, 25-49. [CrossRef] [PubMed]

43. Eaglstein, W.H. Moist wound healing with occlusive dressings: A clinical focus. Dermatol. Surg. 2001, 27, 175-182. [CrossRef] [PubMed]

44. Driver, V.R.; Gould, L.J.; Dotson, P.; Gibbons, G.W.; Li, W.W.; Ennis, W.J.; Kirsner, R.S.; Eaglstein, W.H.; Bolton, L.L.; Carter, M.J. Identification and content validation of wound therapy clinical endpoints relevant to clinical practice and patient values for FDA approval. Part 1. Survey of the wound care community. Wound Repair Regen. 2017, 25, 454-465. [CrossRef] [PubMed]

45. Mouro, C.; Gomes, A.P.; Ahonen, M.; Fangueiro, R.; Gouveia, I.C. Chelidonium majus 1. Incorporated emulsion electrospun PCL/PVA_PEC nanofibrous meshes for antibacterial wound dressing applications. Nanomaterials 2021, 11, 1785. [CrossRef] [PubMed] 
46. Montaser, A.S.; Rehan, M.; EI-Senousy, W.M.; Zaghloul, S. Designing strategy for coating cotton gauze fabrics and its application in wound healing. Carbohydr. Polym. 2020, 244, 116479. [CrossRef] [PubMed]

47. Dhivya, S.; Padma, V.V.; Santhini, E. Wound dressings-A review. Biomedicine 2015, 5, 24-28. [CrossRef] [PubMed]

48. Chaganti, P.; Gordon, I.; Chao, J.H.; Zehtabchi, S. A systematic review of foam dressings for partial thickness burns. Am. J. Emerg. Med. 2019, 37, 1184-1190. [CrossRef] [PubMed]

49. Rezvani Ghomi, E.; Khalili, S.; Nouri Khorasani, S.; Esmaeely Neisiany, R.; Ramakrishna, S. Wound dressings: Current advances and future directions. J. Appl. Polym. Sci. 2019, 136, 1-12. [CrossRef]

50. Cascone, S.; Lamberti, G. Hydrogel-based commercial products for biomedical applications: A review. Int. J. Pharm. 2020, 573, 118803. [CrossRef]

51. Ahmad, A.; Mubarak, N.M.; Jannat, F.T.; Ashfaq, T.; Santulli, C.; Rizwan, M.; Najda, A.; Bin-Jumah, M.; Abdel-Daim, M.M.; Hussain, S.; et al. A critical review on the synthesis of natural sodium alginate based composite materials: An innovative biological polymer for biomedical delivery applications. Processes 2021, 9, 1-27. [CrossRef]

52. Tang, Y.; Lan, X.; Liang, C.; Zhong, Z.; Xie, R.; Zhou, Y.; Miao, X.; Wang, H.; Wang, W. Honey loaded alginate/PVA nanofibrous membrane as potential bioactive wound dressing. Carbohydr. Polym. 2019, 219, 113-120. [CrossRef] [PubMed]

53. Xiao, L.; Jia, G. Modern wound dressing using polymers/biopolymers. J. Mater. Sci. Eng. 2018, 07, 7-10. [CrossRef]

54. Kuznetsova, T.A.; Andryukov, B.G.; Besednova, N.N.; Zaporozhets, T.S.; Kalinin, A.V. Marine algae polysaccharides as basis for wound dressings, drug delivery, and tissue engineering: A review. J. Mar. Sci. Eng. 2020, 8, 481. [CrossRef]

55. Shi, C.; Wang, C.; Liu, H.; Li, Q.; Li, R.; Zhang, Y.; Liu, Y.; Shao, Y.; Wang, J. Selection of appropriate wound dressing for various wounds. Front. Bioeng. Biotechnol. 2020, 8, 1-17.

56. Nuutila, K.; Eriksson, E. Moist wound healing with commonly available dressings. Adv. Wound Care 2021, 1, 1-39.

57. Weller, C.D.; Team, V.; Sussman, G. First-line interactive wound dressing update: A comprehensive review of the evidence. Front. Pharmacology 2020, 11, 1-13. [CrossRef]

58. Palmese, L.L.; Thapa, R.K.; Sullivan, M.O.; Kiick, K.L. Hybrid hydrogels for biomedical applications. Curr. Opin. Chem. Eng. 2019, 24, 143-157. [CrossRef]

59. Varaprasad, K.; Jayaramudu, T.; Kanikireddy, V.; Toro, C.; Sadiku, E.R. Alginatebased composite materials for wound dressing application: A mini review. Carbohydr. Polym. 2020, 236, 116025. [CrossRef]

60. Asanarong, O.; Minh Quan, V.; Boonrungsiman, S.; Sukyai, P. Bioactive wound dressing using bacterial cellulose loaded with papain composite: Morphology, loading/release and antibacterial properties. Eur. Polym. J. 2021, 143, 110224. [CrossRef]

61. Ambekar, R.S.; Kandasubramanian, B. Advancements in nanofibers for wound dressing: A review. Eur. Polym. J. 2019, 117, 304-336. [CrossRef]

62. Mihai, M.M.; Dima, M.B.; Dima, B.; Holban, A.M. Nanomaterials for wound healing and infection control. Materials 2019, $12,2176$. [CrossRef]

63. Wang, C.; Wang, J.; Zeng, L.; Qiao, Z.; Liu, X.; Liu, H.; Zhang, J.; Ding, J. Fabrication of electrospun polymer nanofibers with diverse morphologies. Molecules 2019, 24, 834. [CrossRef]

64. Aidana, Y.; Wang, Y.; Li, J.; Chang, S.; Wang, K.; Yu, D.-G. Fast dissolution electrospun medicated nanofibers for effective delivery of poorly water-soluble drugs. Curr. Drug Deliv. 2021, 18. [CrossRef]

65. Nauman, S.; Lubineau, G.; Alharbi, H.F. Post processing strategies for the enhancement of mechanical properties of enms (Electrospun nanofibrous membranes): A review. Membranes 2021, 11, 1-38. [CrossRef]

66. Ma, H.; Burger, C.; Chu, B.; Hsiao, B.S. Electrospun nanofibers for environmental protection. Handb. Fibrous Mater. 2020, 773-806. [CrossRef]

67. Zhao, K.; Kang, S.X.; Yang, Y.Y.; Yu, D.G. Electrospun functional nanofiber membrane for antibiotic removal in water: Review. Polymers 2021, 13, 1-33. [CrossRef]

68. Wang, M.; Yu, D.-G.; Li, X.; Williams, G.R. The development and bio-applications of multifluid electrospinning. Mater. Highlights 2020, 1, 1-13. [CrossRef]

69. Wang, Y.; Tian, L.; Zhu, T.; Mei, J.; Chen, Z.; Yu, D.G. Electrospun aspirin/Eudragit/lipid hybrid nanofibers for colon-targeted delivery using an energy-saving process. Chem. Res. Chin. Univ. 2021, 37, 443-449. [CrossRef] [PubMed]

70. Li, Y.; Zhu, J.; Cheng, H.; Li, G.; Cho, H.; Jiang, M.; Gao, Q.; Zhang, X. Developments of advanced electrospinning techniques: A critical review. Adv. Mater. Technol. 2021, 2100410. [CrossRef]

71. Xin, R.; Ma, H.; Venkateswaran, S.; Hsiao, B.S. Electrospun nanofibrous adsorption membranes for wasterwater treatment: Mechanical strength enhancement. Chem. Res. Chinese Univ. 2021, 37, 355-365. [CrossRef]

72. Zare, M.; Dziemidowicz, K.; Williams, G.R.; Ramakrishna, S. Encapsulation of pharmaceutical and nutraceutical active ingredients using electrospinning processes. Nanomaterials 2021, 11, 1968. [CrossRef]

73. Buzgo, M.; Mickova, A.; Rampichova, M.; Doupnik, M. Blend electrospinning, coaxial electrospinning, and emulsion electrospinning techniques. In Woodhead Publishing Series in Biomaterials; Woodhead Publishing: Cambridge, UK, 2018 ; pp. 325-347.

74. Wu, J.; Zhang, Z.; Gu, J.; Zhou, W.; Liang, X.; Zhou, G.; Han, C.C.; Xu, S.; Liu, Y. Mechanism of a long-term controlled drug release system based on simple blended electrospun fibers. J. Control. Release 2020, 320, 337-346. [CrossRef]

75. Abdul Hameed, M.M.; Mohamed Khan, S.A.P.; Thamer, B.M.; E1-Enizi, A.; Aldalbahi, A.; El-Hamshary, H.; E1-Newehy, M.H. Core-shell nanofibers from poly (vinyl alcohol) based biopolymers using emulsion electrospinning as drug delivery system for cephalexin drug. J. Macromol. Sci. Part A Pure Appl. Chem. 2020, 58, 130-144. [CrossRef] 
76. Coimbra, P.; Freitas, J.P.; Gonçalves, T.; Gil, M.H.; Figueiredo, M. Preparation of gentamicin sulfate eluting fiber mats by emulsion and by suspension electrospinning. Mater. Sci. Eng. C 2019, 94, 86-93. [CrossRef] [PubMed]

77. Su, S.; Bedir, T.; Kalkandelen, C.; Ozan Başar, A.; Turkoğlu Şaşmazel, H.; Bulent Ustundag, C.; Sengor, M.; Gunduz, O. Coaxial and emulsion electrospinning of extracted hyaluronic acid and keratin based nanofibers for wound healing applications. Eur. Polym. J. 2021, 142, 110158. [CrossRef]

78. Zhan, F.; Yan, X.; Li, J.; Sheng, F.; Li, B. Encapsulation of tangeretin in PVA/PAA crosslinking electrospun fibers by emulsionelectrospinning: Morphology characterization, slowrelease, and antioxidant activity assessment. Food Chem. 2021, $337,127763$. [CrossRef] [PubMed]

79. Rathore, P.; Schiffman, J.D. Beyond the single-nozzle: Coaxial electrospinning enables innovative nanofiber chemistries, geometries, and applications. ACS Appl. Mater. Interfaces 2021, 13, 48-66. [CrossRef] [PubMed]

80. Han, D.; Steckl, A.j. Coaxial electrospinning formation of complex polymer fibers and their applications. Chempluschem 2019, 84, 1453-1497. [CrossRef] [PubMed]

81. Pant, B.; Park, M.; Park, S.J. Drug delivery applications of core-sheath nanofibers prepared by coaxial electrospinning: A review. Pharmaceutics 2019, 11, 305. [CrossRef]

82. Liu, Y.; Chen, X.; Yu, D.G.; Liu, H.; Liu, Y.; Liu, P. Electrospun PVP-core/PHBV-shell nanofibers to eliminate tailing off for an improved sustained release of curcumin. Mol. Pharm. 2021, 438, 232-239.

83. Yan, E.; Jiang, J.; Yang, X.; Fan, L.; Wang, Y.; An, Q.; Zhang, Z.; Lu, B.; Wang, D.; Zhang, D. pH-sensitive core-shell electrospun nanofibers based on polyvinyl alcohol/polycaprolactone as a potential drug delivery system for the chemotherapy against cervical cancer. J. Drug Deliv. Sci. Technol. 2020, 55, 101455. [CrossRef]

84. Wang, M.; Wang, K.; Yang, Y.; Liu, Y.; Yu, D.G. Electrospun environment remediation nanofibers using unspinnable liquids as the sheath fluids: A review. Polymers 2020, 12, 103. [CrossRef]

85. Yu, D.G.; Branford-White, C.J.; Chatterton, N.P.; White, K.; Zhu, L.M.; Shen, X.X.; Nie, W. Electrospinning of concentrated polymer solutions. Macromolecules 2010, 43, 10743-10746. [CrossRef]

86. Gupta, P.; Wilkes, G.L. Some investigations on the fiber formation by utilizing a side-by-side bicomponent electrospinning approach. Polymer 2003, 44, 6353-6359. [CrossRef]

87. Wang, M.; Li, D.; Li, J.; Li, S.; Chen, Z.; Yu, D.G.; Liu, Z.; Guo, J.Z. Electrospun Janus zein-PVP nanofibers provide a two-stage controlled release of poorly water-soluble drugs. Mater. Des. 2020, 196, 109075. [CrossRef]

88. Li, D.; Wang, M.; Song, W.L.; Yu, D.G.; Bligh, S.W.A. Electrospun Janus beads-on-a-string structures for different types of controlled release profiles of double drugs. Biomolecules 2021, 11, 1-15. [CrossRef]

89. Li, R.; Cheng, Z.; Yu, X.; Wang, S.; Han, Z.; Kang, L. Preparation of antibacterial PCL/PVP-AgNP Janus nanofibers by uniaxial electrospinning. Mater. Lett. 2019, 254, 206-209. [CrossRef]

90. Zheng, X.; Kang, S.; Wang, K.; Yang, Y.; Yu, D.G.; Wan, F.; Williams, G.R.; Bligh, S.W. A Combination of structure-performance and shape-performance relationships for better biphasic release in electrospun Janus fibers. Int. J. Pharm. 2021, 596, 120203. [CrossRef] [PubMed]

91. Chang, S.; Wang, M.; Zhang, F.; Liu, Y.; Liu, X.; Yu, D.G.; Shen, H. Sheath-separate-core nanocomposites fabricated using a trifluid electrospinning. Mater. Des. 2020, 192, 108782. [CrossRef]

92. Nagiah, N.; Murdock, C.J.; Bhattacharjee, M.; Nair, L.; Laurencin, C.T. Development of tripolymeric triaxial electrospun fibrous matrices for dual drug delivery applications. Sci. Rep. 2020, 10, 1-11. [CrossRef] [PubMed]

93. Ding, Y.; Dou, C.; Chang, S.; Xie, Z.; Yu, D.G.; Liu, Y.; Shao, J. Core-shell Eudragit S100 nanofibers prepared via triaxial electrospinning to provide a colon-targeted extended drug release. Polymers 2020, 12, 2034. [CrossRef]

94. Zhao, K.; Lu, Z.H.; Zhao, P.; Kang, S.X.; Yang, Y.Y.; Yu, D.G. Modified tri-axial electrospun functional core-shell nanofibrous membranes for natural photodegradation of antibiotics. Chem. Eng. J. 2021, 425, 131455. [CrossRef]

95. Wang, M.; Hou, J.; Yu, D.G.; Li, S.; Zhu, J.; Chen, Z. Electrospun tri-layer nanodepots for sustained release of acyclovir. J. Alloys Compd. 2020, 846, 156471. [CrossRef]

96. Yu, D.G.; Wang, M.; Li, X.; Liu, X.; Zhu, L.M.; Annie Bligh, S.W. Multifluid electrospinning for the generation of complex nanostructures. Wiley Interdiscip. Rev.: Nanomed. Nanobiotechnol. 2020, 12, 1-11. [CrossRef] [PubMed]

97. Zhang, X.; Chi, C.; Chen, J.; Zhang, X.; Gong, M.; Wang, X.; Yan, J.; Shi, R.; Zhang, L.; Xue, J. Electrospun quad-axial nanofibers for controlled and sustained drug delivery. Mater. Des. 2021, 206, 109732. [CrossRef]

98. Wang, F.; Hu, S.; Jia, Q.; Zhang, L. Advances in electrospinning of natural biomaterials for wound dressing. J. Nanomater. 2020, 2020, 8719859. [CrossRef]

99. Memic, A.; Abudula, T.; Mohammed, H.S.; Joshi Navare, K.; Colombani, T.; Bencherif, S.A. Latest progress in electrospun nanofibers for wound healing applications. ACS Appl. Bio Mater. 2019, 2, 952-969. [CrossRef]

100. Juncos Bombin, A.D.; Dunne, N.J.; McCarthy, H.O. Electrospinning of natural polymers for the production of nanofibres for wound healing applications. Mater. Sci. Eng. C 2020, 114, 110994. [CrossRef]

101. Naomi, R.; Bahari, H.; Ridzuan, P.M.; Othman, F. Natural-based biomaterial for skin wound healing (Gelatin vs. collagen): Expert review. Polymers 2021, 13,1-20. [CrossRef]

102. AL-Jbour, N.D.; Beg, M.D.; Gimbun, J.; Alam, A.K.M.M. An overview of chitosan nanofibers and their applications in the drug delivery process. Curr. Drug Deliv. 2019, 16, 272-294. [CrossRef] 
103. Kalantari, K.; Afifi, A.M.; Jahangirian, H.; Webster, T.J. Biomedical applications of chitosan electrospun nanofibers as a green polymer - Review. Carbohydr. Polym. 2019, 207, 588-600. [CrossRef] [PubMed]

104. Bakshi, P.S.; Selvakumar, D.; Kadirvelu, K.; Kumar, N.S. Chitosan as an environment friendly biomaterial - a review on recent modifications and applications. Int. J. Biol. Macromol. 2020, 150, 1072-1083. [CrossRef]

105. Xia, J.; Zhang, H.; Yu, F.; Pei, Y.; Luo, X. Superclear, Porous cellulose membranes with chitosan-coated nanofibers for visualized cutaneous wound healing dressing. ACS Appl. Mater. Interfaces 2020, 12, 24370-24379. [CrossRef]

106. Naomi, R.; Ratanavaraporn, J.; Fauzi, M.B. Comprehensive review of hybrid collagen and silk fibroin for cutaneous wound healing. Materials 2020, 13, 1-22. [CrossRef]

107. Patil, P.P.; Reagan, M.R.; Bohara, R.A. Silk fibroin and silk-based biomaterial derivatives for ideal wound dressings. Int. J. Biol. Macromol. 2020, 164, 4613-4627. [CrossRef]

108. Hadisi, Z.; Farokhi, M.; Bakhsheshi-Rad, H.R.; Jahanshahi, M.; Hasanpour, S.; Pagan, E.; Dolatshahi-Pirouz, A.; Zhang, Y.S.; Kundu, S.C.; Akbari, M. Hyaluronic acid (HA)-based silk fibroin/zinc oxide core-shell electrospun dressing for burn wound management. Macromol. Biosci. 2020, 20, 1-17. [CrossRef]

109. Kothale, D.; Verma, U.; Dewangan, N.; Jana, P.; Jain, A.; Jain, D. Alginate as promising natural polymer for pharmaceutical, food, and biomedical applications. Curr. Drug Deliv. 2020, 17, 755-775. [CrossRef]

110. Kurakula, M.; Rao, G.S.N.K. Pharmaceutical assessment of polyvinylpyrrolidone (PVP): As excipient from conventional to controlled delivery systems with a spotlight on COVID-19 inhibition. J. Drug Deliv. Sci. Technol. 2020, 60, 102046. [CrossRef]

111. Chinatangkul, N.; Tubtimsri, S.; Panchapornpon, D.; Akkaramongkolporn, P.; Limmatvapirat, C.; Limmatvapirat, S. Design and characterization of electrospun shellac-polyvinylpyrrolidone blended micro/nanofibres loaded with monolaurin for application in wound healing. Int. J. Pharm. 2019, 562, 258-270. [CrossRef] [PubMed]

112. Raina, N.; Pahwa, R.; Khosla, J.K.; Gupta, P.N.; Gupta, M. Polycaprolactone-based materials in wound healing applications. Polym. Bull. 2021. [CrossRef]

113. He, J.; Liang, Y.; Shi, M.; Guo, B. Anti-oxidant electroactive and antibacterial nanofibrous wound dressings based on poly(E-caprolactone)/quaternized chitosan-graft-polyaniline for full-thickness skin wound healing. Chem. Eng. J. 2020, 385, 123464. [CrossRef]

114. Teixeira, M.A.; Amorim, M.T.P.; Felgueiras, H.P. Poly (vinyl alcohol)-based nanofibrous electrospun scaffolds for tissue engineering applications. Polymers 2020, 12, 7. [CrossRef]

115. Ali, A.; Mohebbullah, M.; Shahid, M.A.; Alam, S.; Uddin, M.N.; Miah, M.S.; Jamal, M.S.I.; Khan, M.S. PVA-Nigella sativa nanofibrous mat: Antibacterial efficacy and wound healing potentiality. J. Text. Inst. 2020, 1831168. [CrossRef]

116. Zhu, Z.; Liu, Y.; Xue, Y.; Cheng, X.; Zhao, W.; Wang, J.; He, R.; Wan, Q.; Pei, X. Tazarotene released from aligned electrospun membrane facilitates cutaneous wound healing by promoting angiogenesis. ACS Appl. Mater, Interfaces 2019, 11, 36141-36153. [CrossRef] [PubMed]

117. Ramalingam, R.; Dhand, C.; Mayandi, V.; Leung, C.M.; Ezhilarasu, H.; Karuppannan, S.K.; Prasannan, P.; Ong, S.T.; Sunderasan, N.; Kaliappan, I.; et al. Core-Shell structured antimicrobial nanofiber dressings, containing herbal extract and antibiotics combination for the prevention of biofilms and promotion of cutaneous wound healing. ACS Appl. Mater. Interfaces 2021, 13, 24356-24369. [CrossRef] [PubMed]

118. Zou, P.; Lee, W.H.; Gao, Z.; Qin, D.; Wang, Y.; Liu, J.; Sun, T.; Gao, Y. Wound dressing from polyvinyl alcohol/chitosan electrospun fiber membrane loaded with OH-CATH30 nanoparticles. Carbohydr. Polym. 2020, 232, 115786. [CrossRef] [PubMed]

119. Khan, A.R.; Huang, K.; Jinzhong, Z.; Zhu, T.; Morsi, Y.; Aldalbahi, A.; E1-Newehy, M.; Yan, X.; Mo, X. PLCL/Silk fibroin based antibacterial nano wound dressing encapsulating oregano essential oil: Fabrication, characterization and biological evaluation. Colloids Surf. B 2020, 196, 111352. [CrossRef] [PubMed]

120. Li, H.; Chen, X.; Lu, W.; Wang, J.; Xu, Y.; Guo, Y. Application of electrospinning in antibacterial field. Nanomaterials 2021, 11, 1-29. [CrossRef]

121. Keirouz, A.; Chung, M.; Kwon, J.; Fortunato, G.; Radacsi, N. 2D and 3D electrospinning technologies for the fabrication of nanofibrous scaffolds for skin tissue engineering: A review. Wiley Interdiscip. Rev. Nanomed. Nanobiotechnol. 2020, 12, 1-32. [CrossRef] [PubMed]

122. Naskar, A.; Kim, K.S. Recent advances in nanomaterial-based wound-healing therapeutics. Pharmaceutics 2020, 12, 499. [CrossRef]

123. Abdalla, S.S.I.; Katas, H.; Azmi, F.; Busra, M.F.M. Antibacterial and anti-biofilm biosynthesised silver and gold nanoparticles for medical applications: Mechanism of action, toxicity and current status. Curr. Drug Deliv. 2020, 17, 88-100. [CrossRef]

124. Augustine, R.; Hasan, A.; Patan, N.K.; Dalvi, Y.B.; Varghese, R.; Antony, A.; Unni, R.N.; Sandhyarani, N.; Moustafa, A.E.A. Cerium oxide nanoparticle incorporated electrospun poly(3-hydroxybutyrate-co-3-hydroxyvalerate) membranes for diabetic wound healing applications. ACS Biomater. Sci. Eng. 2020, 6, 58-70. [CrossRef]

125. Yang, J.; Wang, K.; Yu, D.G.; Yang, Y.; Bligh, S.W.A.; Williams, G.R. Electrospun Janus nanofibers loaded with a drug and inorganic nanoparticles as an effective antibacterial wound dressing. Mater. Sci. Eng. C 2020, 111, 110805. [CrossRef]

126. Jafari, A.; Amirsadeghi, A.; Hassanajili, S.; Azarpira, N. Bioactive antibacterial bilayer PCL/gelatin nanofibrous scaffold promotes full - thickness wound healing. Int. J. Pharm. 2020, 583, 119413. [CrossRef]

127. Samadian, H.; Zamiri, S.; Ehterami, A.; Farzamfar, S.; Vaez, A.; Khastar, H.; Alam, M.; Ai, A.; Derakhshankhah, H.; Allahyari, Z.; et al. Electrospun cellulose acetate/gelatin nanofibrous wound dressing containing berberine for acetate/gelatin nanofibrous wound dressing containing berberine diabetic foot ulcer healing: In vitro and in vivo studies. Sci. Rep. 2020, 10, 1-12. [CrossRef] 
128. López-Calderón, H.D.; Avilés-Arnaut, H.; Galán Wong, L.J.; Almaguer - Cantú, V.; Laguna-Camacho, J.R.; Calderón-Ramón, C.; Escalante- Martínez, J.E.; Arévalo-Niño, K. Electrospun polyvinylpyrrolidone-gelatin and cellulose acetate bi-Layer scaffold loaded with gentamicin as possible wound dressing. Polymers 2020, 12, 2311. [CrossRef]

129. Ahmadian, S.; Ghorbani, M.; Mahmoodzadeh, F. Silver sulfadiazine-loaded electrospun ethyl cellulose/polylactic acid/collagen nanofibrous mats with antibacterial properties for wound healing. Int. J. Biol. Macromol. 2020, 162, 1555-1565. [CrossRef] [PubMed]

130. Ghorbani, M.; Nezhad-Mokhtari, P.; Ramazani, S. Aloe vera-loaded nanofibrous scaffold based on zein/polycaprolactone/collagen for wound healing. Int. J. Biol. Macromol. 2020, 153, 921-930. [CrossRef] [PubMed]

131. Yang, S.; Li, X.; Liu, P.; Zhang, M.; Wang, C.; Zhang, B. Multifunctional chitosan/polycaprolactone nanofiber scaffolds with varied dual-drug release for wound-healing applications. ACS Biomater. Sci. Eng. 2020, 6, 4666-4676. [CrossRef] [PubMed]

132. Ribeiro, A.S.; Costa, S.M.; Ferreira, D.P.; Calhelha, R.C.; Barros, L.; Stoiković, D.; Soković, M.; Ferreira, I.C.F.R.; Fangueiro, R. Chitosan/nanocellulose electrospun fibers with enhanced antibacterial and antifungal activity for wound dressing applications. React. Funct. Polym. 2021, 159, 104808. [CrossRef]

133. Peng, Y.; Ma, Y.; Bao, Y.; Liu, Z.; Chen, L.; Dai, F.; Li, Z. Electrospun PLGA/SF/artemisinin composite nanofibrous membranes for wound dressing. Int. J. Biol. Macromol. 2021, 183, 68-78. [CrossRef]

134. Agarwal, Y.; Rajinikanth, P.S.; Ranjan, S.; Tiwari, U.; Balasubramnaiam, J.; Pandey, P.; Arya, D.K.; Anand, S.; Deepak, P. Curcumin loaded polycaprolactone-/polyvinyl alcohol-silk fibroin based electrospun nanofibrous mat for rapid healing of diabetic wound: An in-vitro and in-vivo studies. Int. J. Biol. Macromol. 2021, 176, 376-386. [CrossRef] [PubMed]

135. Najafiasl, M.; Osfouri, S.; Azin, R.; Zaeri, S. Alginate-based electrospun core/shell nanofibers containing dexpanthenol: A good candidate for wound dressing. J. Drug Deliv. Sci. Technol. 2020, 57, 101708. [CrossRef]

136. Najafi, S.; Gholipour- Kanani, A.; Eslahi, N.; Bahrami, S.H. Study on release of cardamom extract as an antibacterial agent from electrospun scaffold based on sodium alginate. J. Text. Inst. 2021, 112, 1482-1490. [CrossRef]

137. Hajikhani, M.; EMAM-Djomeh, Z.; Askari, G. Fabrication and characterization of mucoadhesive bioplastic patch via coaxial polylactic acid (PLA) based electrospun nanofibers with antimicrobial and wound healing application. Int. J. Biol. Macromol. 2021, 172, 143-153. [CrossRef] [PubMed]

138. Yin, J.; Xu, L. Batch preparation of electrospun polycaprolactone/chitosan/aloe vera blended nanofiber membranes for novel wound dressing. Int. J. Biol. Macromol. 2020, 160, 352-363. [CrossRef] [PubMed]

139. Fahimirad, S.; Abtahi, H.; Satei, P.; Ghaznavi-Rad, E.; Moslehi, M.; Ganji, A. Wound healing performance of PCL/chitosan based electrospun nanofiber electrosprayed with curcumin loaded chitosan nanoparticles. Carbohydr. Polym. 2021, 259, 117640. [CrossRef]

140. El Fawal, G.; Hong, H.; Mo, X.; Wang, H. Fabrication of scaffold based on gelatin and polycaprolactone (PCL) for wound dressing application. J. Drug Deliv. Sci. Technol. 2021, 63, 102501. [CrossRef]

141. Ghiyasi, Y.; Salahi, E.; Esfahani, H. Synergy effect of Urtica dioica and ZnO NPs on microstructure, antibacterial activity and cytotoxicity of electrospun PCL scaffold for wound dressing application. Mater. Today Commun. 2021, 26, 102163. [CrossRef]

142. Unalan, I.; Endlein, S.J.; Slavik, B.; Buettner, A.; Goldmann, W.H.; Detsch, R.; Boccaccini, A.R. Evaluation of electrospun poly(E-caprolactone)/gelatin nanofiber mats containing clove essential oil for antibacterial wound dressing. Pharmaceutics 2019, 11, 570. [CrossRef]

143. Adeli, H.; Khorasani, M.T.; Parvazinia, M. Wound dressing based on electrospun PVA/chitosan/starch nanofibrous mats: Fabrication, antibacterial and cytocompatibility evaluation and in vitro healing assay. Int. J. Biol. Macromol. 2019, 122, 238-254. [CrossRef] [PubMed]

144. Wang, S.; Yan, F.; Ren, P.; Li, Y.; Wu, Q.; Fang, X.; Chen, F.; Wang, C. Incorporation of metal-organic frameworks into electrospun chitosan/poly (vinyl alcohol) nanofibrous membrane with enhanced antibacterial activity for wound dressing application. Int. J. Biol. Macromol. 2020, 158, 9-17. [CrossRef] [PubMed]

145. Kalalinia, F.; Taherzadeh, Z.; Jirofti, N.; Amiri, N.; Foroghinia, N.; Beheshti, M.; Bazzaz, B.S.F.; Hashemi, M.; Shahroodi, A.; Pishavar, E.; et al. Evaluation of wound healing efficiency of vancomycin-loaded electropunk chitosan/poly ethylene oxide nanofibers in full thickness wound model of rat. Int. J. Biol. Macromol. 2021, 177, 100-110. [CrossRef] [PubMed]

146. Amiri, N.; Ajami, S.; Shahroodi, A.; Jannatabadi, N.; Amiri Darban, S.; Fazly Bazzaz, B.S.; Pishavar, E.; Kalalinia, F.; Movaffagh, J. Teicoplanin-loaded chitosan-PEO nanofibers for local antibiotic delivery and wound healing. Int. J. Biol. Macromol. 2020, 162, 645-656. [CrossRef]

147. Dong, W.H.; Liu, J.X.; Mou, X.J.; Liu, G.S.; Huang, X.W.; Yan, X.; Ning, X.; Ning, X.; Russell, S.J.; Long, Y.Z. Performance of polyvinyl pyrrolidone-isatis root antibacterial wound dressings produced in situ by handheld electrospinner. Colloids Surf. B 2020, 188, 110766. [CrossRef]

148. Qin, M.; Mou, X.J.; Dong, W.H.; Liu, J.X.; Liu, H.; Dai, Z.; Huang, X.W.; Wang, N.; Yan, X. In situ electrospinning wound healing films composed of zein and clove essential oil. Macromol. Mater. Eng. 2020, 305, 1-6. [CrossRef]

149. Yue, Y.; Gong, X.; Jiao, W.; Li, Y.; Yin, X.; Si, Y.; Yu, J.; Ding, B. In-situ electrospinning of thymol-loaded polyurethane fibrous membranes for waterproof, breathable, and antibacterial wound dressing application. J. Colloid Interface Sci. 2021, 592, 310-318. [CrossRef]

150. Xu, H.; Xu, X.; Li, S.; Song, W.-L.; Yu, D.-G.; Annie Bligh, S.W. The effects of drug heterogeneous distributions with core-sheath nanostructures on its sustained release profiles. Biomolecules 2021, 11, 1330. [CrossRef] 
151. Xiaoxia, X.; Jing, S.; Dongbin, X.; Yonggang, T.; Jingke, Z.; Hulai, W. Realgar nanoparticles inhibit migration, invasion and metastasis in a mouse model of breast cancer by suppressing matrix metalloproteinases and angiogenesis. Curr. Drug Deliv. 2020, 17, 148-158. [CrossRef]

152. Eskiler, G.G.; Cecener, G.; Dikmen, G.; Egeli, U.; Tunca, B. Talazoparib loaded solid lipid nanoparticles: Preparation, characterization and evaluation of the therapeutic efficacy in vitro. Curr. Drug Deliv. 2019, 16, 511-529. [CrossRef]

153. Tan, G.Z.; Zhou, Y. Electrospinning of biomimetic fibrous scaffolds for tissue engineering: A review. Int. J. Polym. Mater. Polym. Biomater. 2019, 69, 947-960. [CrossRef]

154. Islam, M.S.; Ang, B.C.; Andriyana, A.; Afifi, A.M. A review on fabrication of nanofibers via electrospinning and their applications. SN Appl. Sci. 2019, 1, 1-16. [CrossRef]

155. Yang, X.; Wang, J.; Guo, H.; Liu, L.; Xu, W.; Duan, G. Structural design toward functional materials by electrospinning: A review. E-Polymers 2020, 20, 682-712. [CrossRef] 